\title{
Synthesis and Characterization of ( $\pi$-allyl)Palladium(II) Complexes Containing Dialkylbiaryl Phosphine Ligands
}

\author{
Katherine R. McGarry, Michael McDaniel, Benny C. Chan, and Abby R. O'Connor \\ Department of Chemistry, The College of New Jersey, 2000 Pennington Road, Ewing, New \\ Jersey 08628-0718
}

\begin{abstract}
Neutral ( $\pi$-allyl)palladium(II) halide complexes, which are air and moisture tolerant, containing dialkylbiaryl (alkyl $=$ cyclohexyl or $t$-butyl) phosphine ligands, have been synthesized and characterized by ${ }^{1} \mathrm{H},{ }^{31} \mathrm{P},{ }^{13} \mathrm{C}$ NMR spectroscopy, X-ray crystallography, and elemental analysis. Exposure of the halide complexes to sodium tetrakis(3,5-bis(trifluoromethyl)tetraphenylborate) $\left(\operatorname{NaB}\left(\mathrm{Ar}_{\mathrm{F}}\right)_{4}\right)$ yields $(\pi$-allyl)palladium(II) cations, in which coordination of the pendent lower ring of the biphenyl moiety of the dialkylbiaryl phosphine ligand occurs. These cations have been characterized by ${ }^{1} \mathrm{H},{ }^{31} \mathrm{P},{ }^{13} \mathrm{C}$ NMR spectroscopy, X-ray crystallography, and elemental analysis. The cationic complexes are not fluxional on the NMR timescale and a significant interaction exists between palladium and the arene group.
\end{abstract}

Keywords: Pd(II) complexes, Metal-arene interactions, Phosphines, X-ray structure

Introduction

( $\pi$-Allyl)palladium complexes are ubiquitous in organometallic chemistry. A large number of these complexes containing different ancillary ligands have been synthesized, characterized, and utilized for a variety of catalytic applications.[1] For example, the in situ reaction of ( $\pi$-allyl)palladium halide complexes coordinated to a phosphine ligand with sodium salts containing a weakly coordinating counteranion yield active catalysts for norbornene polymerization at $65^{\circ} \mathrm{C}$.[2] ( $\pi$-Allyl)palladium complexes have also been used to catalyze reactions involving the nucleophilic addition of a heteroatom or carbon nucleophile to an allyl 
moiety. Quite recently, Hazari evaluated the plausibility of $\left(\pi\right.$-allyl-Pd $\left.-\mathrm{Pd}^{\mathrm{I}}\right)$ dimers, as precatalysts, for the Suzuki-Miyuara reaction. Through elegant mechanistic experiments, it was discovered that $\mathrm{Pd}^{\mathrm{I}}$ dimers could be obtained, in situ, from readily synthesized $(\pi$ allyl)Pd(ligand) $\mathrm{Cl}$ complexes in the presence of base and these dimers likely impede formation of the active $\operatorname{Pd}(0)$ catalyst.[3] Widenhoefer evaluated the use of in situ generated cationic $(\pi-$ allyl)palladium phosphine complexes to catalyze the cycloisomerization of functionalized 1,6dienes. It was found that $\pi$-allyl palladium phosphine complexes, such as $\left(\eta^{3}-\mathrm{C}_{3} \mathrm{H}_{5}\right) \mathrm{Pd}(\mathrm{Cl}) \mathrm{PR}$, in conjunction with $\mathrm{NaB}\left(\mathrm{Ar}_{\mathrm{F}}\right)_{4}\left(\mathrm{Ar}_{\mathrm{F}}=3\right.$,5-bis-(trifluoromethyl)phenyl, $\mathrm{R}=\mathrm{Cy}, \mathrm{Cyp}$, or ${ }^{i} \mathrm{Pr}$ ) yielded 1,2-disubstituted cyclopentane products in high yield and selectivity at $70^{\circ} \mathrm{C}$ and $25^{\circ} \mathrm{C}$.[4] However, no product was formed when the phosphines used were dialkylbiaryl phosphines and no effort was made to isolate the cationic palladium species formed in these systems.

The use of arene moieties to stabilize low coordinate metal centers has been an effective strategy to generate reactive complexes for catalytic applications.[5,6] In many instances, the metal-arene interaction is weak and is considered hemilabile. For example, rhodium complexes containing (phosphinoalkyl)arene ligands exhibit a labile arene interaction to the metal center that can be displaced by free arene.[7] Additionally, Brookhart and coworkers demonstrated $\eta^{6}$ arene coordination to $\mathrm{Pd}(\mathrm{II})$ and $\mathrm{Ni}(\mathrm{II})$ cations[6] and these complexes were utilized as initiators for diene, styrene,[8] and norbornene[9,10] polymerization. Different coordination modes of the lower pendent ring of Buchwald type phosphines have been observed in $\mathrm{Rh}[5]$ and $\operatorname{Ir}[11]$ complexes.

Dialkylbiaryl phosphine ligands are an important class of ligands in organometallic chemistry. These ligands have been coordinated to a number of different transition metal centers.[5,11-16] In particular, they have been important in palladium-catalyzed coupling 
reactions studied by Buchwald.[17] The use of dialkylbiaryl phosphines improved the stability of $\operatorname{Pd}(0)$ complexes used to catalyze coupling reactions.[13] Additionally, the lower pendent arene group shields the Pd center, preventing self-aggregation and oxidation. Buchwald and coworkers evaluated the use of electron-withdrawing and electron-donating groups on the arene rings of the biphenyl moiety and discovered that the addition of electron-donating groups on the $2^{\prime}$ and $6^{\prime}$ positions of the lower arene stabilized the palladium center. Additionally, the ortho- and ipsocarbons of the lower ring often exhibit weak interaction with the metal center, stabilizing reactive open sites. DFT calculations have been conducted and identify that the metal-arene interaction is weak and the arene dissociates from the metal center when catalysis occurs.[18]

Despite the large number of examples of $\mathrm{Pd}(0)$ and $\mathrm{Pd}(\mathrm{II})$ complexes containing dialkylbiaryl phosphines, there are limited reports of these ligands coordinated to ( $\pi$-allyl)Pd(II) fragments. Previously, Faller evaluated the coordination of a dialkylbiaryl phosphine ligand containing a dimethylamino $\left(\mathrm{NMe}_{2}\right)$ group in the 2' position of the lower ring on a cationic $(\pi-$ allyl)Pd fragment. Coordination of the palladium center to the arene, as well as to the $\mathrm{NMe}_{2}$ group, is observed and variable temperature NMR studies were conducted to evaluate this behavior.[12] As mentioned above, Widenhoefer described the synthesis and application of ( $\pi$ allyl)Pd(dialkylbiaryl phosphine) chloride (alkyl $=\mathrm{Cy}$ or ${ }^{t} \mathrm{Bu}$ ).[4] Quite recently, Colacot and coworkers described the preparation and characterization of ( $\pi$-allyl) $\mathrm{PdCl}$ complexes and ( $\pi$ allyl)Pd triflate cations containing a variety of dialkylbiaryl phosphine ligands.[14] These complexes serve as highly reactive precatalysts for coupling reactions. Hazari also reported $\left(\eta^{3}-\right.$ indenyl)Pd(dialkylbiaryl phosphine) halides that serve as robust and active precatalysts for coupling reactions. These species do not form $\mathrm{Pd}^{\mathrm{I}}$ dimers, as previously observed with $\pi$-allyl $\mathrm{Pd}$ systems.[15] In most cases, the neutral ( $\pi$-allyl)Pd(II) complexes containing Buchwald-type 
ligands possess a chloride halogen ligand. Additionally, to date few ( $\pi$-allyl)Pd(II) complexes containing this class of ligands have been characterized crystallographically[12,15] and structural analysis is limited. There are also no reports of cationic complexes containing bulky non-coordinating anions, such as $\mathrm{B}\left(\mathrm{Ar}_{\mathrm{F}}\right)_{4}{ }^{-} \quad\left(\mathrm{B}\left(\mathrm{Ar}_{\mathrm{F}}\right)_{4}{ }^{-}=\right.$tetrakis $(3,5-$ bis(trifluoromethyl)tetraphenylborate).

This work expands upon this area and we report the synthesis of neutral and cationic ( $\pi$ allyl)palladium(II) complexes containing dialkylbiaryl phosphine ligands. The dialkylbiaryl phosphines evaluated either have cyclohexyl or tbutyl groups. We have also evaluated substitution on the lower ring, varying the substituents from hydrogen $(\mathrm{H})$, to methoxy $(\mathrm{OMe})$, to methyl (Me), and to isopropyl $\left({ }^{i} \mathrm{Pr}\right)$. Coordination of the lower arene ring to the palladium center is observed in all of the cationic complexes. The arene interaction to palladium has been evaluated using X-ray crystallography. The hapticity observed is dependent on the presence of substitutes on the lower pendent ring. The arene to palladium interaction could provide access to a highly reactive 14-electron cationic palladium species that could be used to catalyze polymerization of norbornene and other olefinic monomers.

\section{Results and Discussion}

\section{Synthesis of ( $\pi$-Allyl)palladium(II) Halide Complexes Containing Dialkylbiaryl Phosphine}

\section{Ligands.}

Synthesis of the palladium halides was achieved using a modified literature procedure.[19] The reaction of $\pi$-allyl palladium halide dimer $\left.\left(\eta-\mathrm{C}_{3} \mathrm{H}_{5}\right)_{2} \mathrm{Pd}_{2} \mathrm{X}_{2}\right),(\mathrm{X}=\mathrm{Br}, \mathrm{Cl})$ and commercially available dialkylbiaryl phosphine ligands in diethyl ether affords $(\pi$ allyl)PdP(biAr) $\mathrm{R}_{2} \mathrm{X}$ complexes 1a-6a $\left(\mathrm{X}=\mathrm{Cl}\right.$ or $\mathrm{Br}$, biAr $=$ biaryl, $\left.\mathrm{R}_{2}=\mathrm{Cy},{ }^{t} \mathrm{Bu}\right)$ in respectable 
yields (37-76\%) and high purity (Scheme 1). Complexes 1a-6a were characterized using ${ }^{1} \mathrm{H},{ }^{31} \mathrm{P}$, and ${ }^{13} \mathrm{C}$ NMR spectroscopy and elemental analysis. Suitable elemental analysis could not be obtained for complex 6a. The synthesis and characterization of complex 1a was recently reported in the literature.[14]

Complexes 1a, 2a, 3a, 5a, and 6a displayed a single resonance in the ${ }^{31} \mathrm{P}$ NMR spectrum that was shifted downfield compared to the free ligand and verified that the phosphine was bound to the palladium center (Table 1). Two ${ }^{31} \mathrm{P}$ resonances at $\delta 34.1$ and 31.0 are observed for complex $4 \mathbf{a}$ in a 1:1 ratio. There are two isomers for this complex in solution due to the methyl group in the 2'-position of the lower ring. The two isomers do not interconvert on the NMR timescale at room temperature. In converse, only one ${ }^{31} \mathrm{P}$ resonance at $56.1 \mathrm{ppm}$ is observed for the analogous ${ }^{t} \mathrm{Bu}$ substituted complex $\mathbf{6 a}$ at room temperature.

The ${ }^{1} \mathrm{H}$ NMR spectra for complexes 1a-4a are sharp at room temperature. There are five individual resonances observed for the allyl hydrogens due to the unsymmetrical nature around the palladium center. The presence of five allyl signals in the ${ }^{1} \mathrm{H}$ NMR suggests that there is no fluxional behavior for these complexes on the NMR timescale. The allyl proton shifts appear in the range of 5.3-2.3 ppm for all of the complexes. Other diagnostic features can be assigned to the different substituents on the lower pendent ring. For complex 1a, four sets of doublets assigned to the isopropyl groups are observed in the NMR spectrum. Complex 2a exhibits two singlets at 3.70 and $3.64 \mathrm{ppm}$ corresponding to the methoxy group. Two sets of signals are observed in the ${ }^{1} \mathrm{H}$ NMR spectrum of complex $4 \mathbf{a}$. There are two singlets assigned to the methyl groups at 2.10 and $2.03 \mathrm{ppm}$ along with 10 individual resonances for the different allyl hydrogens for each isomer. The presence of two methyl signals along with two sets of allyl signals supports the presence of two isomers present solution. The ratio of the two isomers is 1:1 
and there is no fluxional behavior observed at room temperature on the NMR timescale. Only one set of allyl resonances is observed for complex $\mathbf{6 a}$ at room temperature, consistent with a single ${ }^{31} \mathrm{P}$ resonance. In complexes 1a-4a the Cy resonances appear as multiplets in the range of 2.3-0.9 ppm. The ${ }^{t} \mathrm{Bu}$ signals for $\mathbf{6 a}$ appear as doublets at $1.50(\mathrm{~d}, J=13.6 \mathrm{~Hz}, 9 \mathrm{H}), 1.38(\mathrm{~d}, J=$ 13.4 Hz, 9H) ppm, while a single doublet is observed for complex $\mathbf{5 a}$ at $1.46(\mathrm{~d}, J=13.4 \mathrm{~Hz}$, $\left.18 \mathrm{H},{ }^{t} \mathrm{Bu}\right) \mathrm{ppm}$.

Scheme 1. Synthesis of ( $\pi$-allyl)palladium(dialkylbiaryl phosphine)halide complexes 1a-6a.

Table 1. Comparison of ${ }^{31} \mathrm{P}$ NMR shifts $\left(\mathrm{CDCl}_{3}, 122 \mathrm{MHz}\right)$ for free phosphine ligands vs. complexes 1a-6a.

\begin{tabular}{|c|c|c|}
\hline Complex & Free ligand (ppm) & Bound Ligand (ppm) \\
\hline $\mathbf{1 a}$ & -11.3 & 48.4 \\
\hline $\mathbf{2 a}$ & -8.1 & $35.2^{\mathrm{a}}$ \\
\hline $\mathbf{3 a}$ & -12.2 & 28.7 \\
\hline $\mathbf{4 a}$ & -10.6 & $34.1,31.0$ \\
\hline $\mathbf{5 a}$ & 19.1 & 55.4 \\
\hline $\mathbf{6 a}$ & 21.3 & 56.1 \\
\hline
\end{tabular}

a. Sample analyzed in $\mathrm{CD}_{2} \mathrm{Cl}_{2}$.

X-ray quality crystals of sixteen electron complexes $4 \mathbf{a}$ and $\mathbf{5 a}$ were obtained by layering a dichloromethane solution of the complex with pentane and storing at $-28^{\circ} \mathrm{C}$. The molecular structures for 4a and 5a were determined by X-ray crystallography and the ORTEPs for halide complexes 4a and 5a are found in Figures 1 and 2 and corresponding details are found in the Supporting Information (Table SI 1). Relevant bond distances are found in Tables 2 and 3. The coordination geometry around palladium is approximately square planar with a $\pi$-allyl ligand, bromide, and phosphine ligand occupying the square plane. The $\mathrm{Pd}-\mathrm{C}_{\text {allyl }}$ bond distances are consistent with a ( $\pi$-allyl)palladium halide containing a dialkylbiaryl phosphine.[14] The $\mathrm{Pd}^{-\mathrm{C}_{1}}$ $(2.175(5) \AA)$ bond distance is longer than the $\mathrm{Pd}_{-} \mathrm{C}_{3}(2.152(3) \AA)$ distance in 4a due to the stronger trans influence of the phosphine ligand relative to the bromide ligand. A similar finding 
is observed in 5a $\left(\mathrm{Pd}_{1}-\mathrm{C}_{1} 2.163(8) \AA\right.$ vs. $\left.\mathrm{Pd}_{1}-\mathrm{C}_{3} 2.196(9) \AA\right)$. No palladium to arene interaction is observed in the solid-state structures for $\mathbf{4 a}$ and $\mathbf{5 a}$.

Figure 1. ORTEP for ( $\quad$-allyl)palladium(2-dicyclohexylphosphino-2'methylbiphenyl)bromide), 4a. Hydrogen atoms are omitted for clarity. Ellipsoids are drawn at $50 \%$.

Table 2. Selected bond lengths for complex $4 \mathbf{4 a}$.

\begin{tabular}{|c|c|}
\hline Bond & Bond Length $(\AA)$ \\
\hline Pd1-C1 & $2.175(5)$ \\
\hline Pd1-C2A & $2.129(6)$ \\
\hline Pd1-C3 & $2.152(3)$ \\
\hline Pd1-Br1 & $2.505(8)$ \\
\hline Pd1-P1 & $2.323(1)$ \\
\hline C1-C2A & $1.276(8)$ \\
\hline C2A-C3 & $1.410(8)$ \\
\hline
\end{tabular}

Figure 2. ORTEP of ( $\pi$-allyl)palladium(2-di- ${ }^{t}$ butylphosphinobiphenyl)bromide, 5a. Hydrogen atoms are omitted for clarity. Ellipsoids are drawn at 50\%.

Table 3. Selected bond lengths for complex 5a.

\begin{tabular}{|c|c|}
\hline Bond & Bond Length $(\AA)$ \\
\hline Pd1-C1 & $2.163(8)$ \\
\hline Pd1-C2A & $2.15(1)$ \\
\hline Pd1-C3 & $2.196(9)$ \\
\hline Pd1-Br1 & $2.517(2)$ \\
\hline Pd1-P1 & $2.372(3)$ \\
\hline C1-C2A & $1.38(2)$ \\
\hline C2A-C3 & $1.33(2)$ \\
\hline
\end{tabular}

\section{Synthesis of Cationic ( $\pi$-allyl)Palladium(II) Complexes Containing Dialkylbiaryl Phosphine}

\section{Ligands.}

Reaction of halide complexes 1a-6a with $\mathrm{NaB}\left(\mathrm{Ar}_{\mathrm{F}}\right)_{4}$ in dichloromethane resulted in removal of the halide ligand and formation of cationic $\operatorname{Pd}(\mathrm{II})$ species 1-6. The cationic palladium species were obtained in high purity and moderate to good yields (55-92\%) (Scheme 2). In contrast to previous work by Pörschke, $\mathrm{NaB}\left(\mathrm{Ar}_{\mathrm{F}}\right)_{4}$ effectively removes the halide ligand from the 
palladium center generating square planar Pd(II) cations with bulky phosphine ligands. Pörschke found that reaction ( $\pi$-allyl)Pd phosphine halide complexes with lithium, silver, or thallium salts containing weakly coordinating counteranions resulted in consumption of only half an equivalent of salt and formation of bridging halide complexes of the form $\left[(\pi \text {-allylPdPR })_{2}(\mu-X)\right][Y]$, where $\mathrm{X}=$ halide, $\mathrm{Y}=$ non-coordinating anion.[20] These complexes result from incomplete metathesis of the Pd-halide bond and complete abstraction was only achieved using more reactive AgOTf. We have observed these bridging halide dimeric species by ${ }^{1} \mathrm{H}$ and ${ }^{31} \mathrm{P}$ NMR spectroscopy when only 0.5 equiv of $\mathrm{NaB}\left(\mathrm{Ar}_{\mathrm{F}}\right)_{4}$ is used, which is consistent with $\mathrm{NMR}$ data reported by Pörschke.[20] In contrast, Pörschke isolated monomeric ( $\pi$-allyl)Pd(NHC)(OTf) upon addition of AgOTf to ( $\pi$-allyl)Pd(NHC)Cl complexes,[21] similar to our findings.

Scheme 2. Synthesis of [( $\pi$-allyl)palladium(dialkylbiaryl phosphine) $]\left[\mathrm{B}\left(\mathrm{Ar}_{\mathrm{F}}\right)_{4}\right]$ complexes 1-6.

Complexes 1-6 were characterized via ${ }^{1} \mathrm{H},{ }^{31} \mathrm{P}$, and ${ }^{13} \mathrm{C}$ NMR spectroscopy, and elemental analysis. The arene to metal interaction was verified through X-ray crystallography. The presence of a single ${ }^{31} \mathrm{P}$ resonance shifted downfield verified that the phosphine was bound to the metal center for complexes 1-3 and 5. All ${ }^{1} \mathrm{H}$ NMR spectra obtained were sharp, which indicates that the arene is not dissociating from the metal on the NMR timescale. Five individual resonances are observed for the five inequivalent allyl hydrogens, consistent with other $(\pi-$ allyl)Pd(phosphine) cations.[2] Two sets of signals in a 1:1 ratio are observed in the ${ }^{1} \mathrm{H}$ NMR spectra for complex 4. Two singlets are observed at 46.2 and $45.1 \mathrm{ppm}$ in the ${ }^{31} \mathrm{P}$ of complex 4 . Complex 6 exhibits two singlets at 75.0 and $72.5 \mathrm{ppm}$ in the ${ }^{31} \mathrm{P}$ NMR in a ratio of 1:0.6. The presence of two sets of sharp signals in the ${ }^{1} \mathrm{H}$ spectrum along with two singlets in the ${ }^{31} \mathrm{P}$ NMR for complex $\mathbf{4}$ and $\mathbf{6}$ support two isomers that are not interconverting on the NMR timescale. 
X-ray quality crystals of complexes 4,5 , and 6 were obtained by layering a concentrated dichloromethane solution of the complex with pentane at $-28^{\circ} \mathrm{C}$. X-ray diffraction was used to determine the molecular structure of the cationic palladium complexes in the solid state. ORTEPs of the cationic complexes 4, 5, and $\mathbf{6}$ are found in Figures $3-5$ and relevant bond distances are found in Tables $4-6$. All other X-ray parameters are found in the Supporting Information. All complexes exhibit approximately square planar geometry with the phosphorus, $\pi$-allyl group, and the pendent arene in the square plane. Although two rotamers of $\mathbf{4}$ and $\mathbf{6}$ are observed in solution, only one rotamer of each was observed in the solid state. The isomer observed in the solid state has the methyl group pointing towards the allyl for complex 4 (Figure 3) and the methyl group pointing away from the allyl for complex 6 (Figure 5). Longer Pd- $\mathrm{C}_{\text {allyl }}$ bond distances, 2.116(5) $\AA, 2.248(3) \AA, 2.249(6) \AA$ for 4, 5, 6, respectively, are observed for those trans to the phosphine due to the stronger trans influence of phosphorus. Different coordination modes are observed between the palladium center and the arene moiety. Complex 5 exhibits an $\eta^{1}$-coordination palladium to arene interaction, as indicated by the short $\mathrm{Pd}_{1}-\mathrm{C}_{9}$ contact $(2.357(3) \AA)$. The proximal arene carbons $\left(\mathrm{C}_{4}\right.$ and $\left.\mathrm{C}_{8}\right)$ are too far away for interaction $(<$ $2.5 \AA$ ) with the palladium center in the solid state. A similar $\eta^{1}$-interaction of a bulkier Buchwald phosphine to a ( $\pi$-allyl)Pd cation was observed in the solid state.[14] The C-C distances, $\mathrm{C}_{8}-\mathrm{C}_{9}$ and $\mathrm{C}_{4}-\mathrm{C}_{9}$, are approximately the same, 1.416(4) $\AA$ and 1.403(4) $\AA$, respectively. In contrast, an $\eta^{2}$-interaction to the lower pendent ring is observed for a neutral Pd(II) methyl triflate complex coordinated to $\mathrm{P}^{t} \mathrm{Bu}_{2} \mathrm{biPh}$.[22] For complexes $\mathbf{4}$ and $\mathbf{6}$, an $\eta^{2}$ interaction exists between palladium and the arene $\left(\mathrm{Pd}_{1}-\mathrm{C}_{4}=2.447(4) \AA\right.$ and $\mathrm{Pd}_{1}-\mathrm{C}_{5}=2.402(4) \AA$ for $4, \mathrm{Pd}_{1}-\mathrm{C}_{4}=2.425(3) \AA, \mathrm{Pd}_{1}-\mathrm{C}_{5}$ $=2.392(4) \AA$ for 6$)$. Elongation of the $\mathrm{C}-\mathrm{C}$ double bond of the pendent arene $\left(\mathrm{C}_{4}-\mathrm{C}_{5}\right)$ upon $\eta^{2}-$ coordination to Pd is observed (1.431(7) $\AA$ for 4 and 1.418(5) $\AA$ for 6). In comparison, the 
average $\mathrm{C}-\mathrm{C}$ bond length within the lower phenyl ring of the dialkylbiaryl phosphine that does not interact with $\mathrm{Pd}$ is approximately $1.38 \AA$ for complexes $\mathbf{4}$ and $\mathbf{6}$. Similar elongation is observed in Faller's ( $\pi$-allyl)Pd cation containing a Buchwald phosphine.[12]

Figure 3. ORTEP of [( $\pi$-allyl)palladium(2-dicyclohexylphosphino-2'methylbiphenyl $)]\left[\mathrm{B}\left(\mathrm{Ar}_{\mathrm{F}}\right)_{4}\right]$, 4. Counteranion and hydrogen atoms are omitted for clarity. Ellipsoids are drawn at 50\%.

Table 4. Selected bond lengths for complex 4.

\begin{tabular}{|c|c|}
\hline Bond & Bond Length $(\AA)$ \\
\hline Pd1-C1 & $2.116(5)$ \\
\hline Pd1-C2 & $2.136(7)$ \\
\hline Pd1-C3 & $2.251(6)$ \\
\hline Pd1-C4 & $2.447(4)$ \\
\hline Pd1-C5 & $2.402(4)$ \\
\hline Pd1-P1 & $2.282(1)$ \\
\hline C4-C5 & $1.431(7)$ \\
\hline C1-C2 & $1.329(8)$ \\
\hline C1-C2 & $1.256(9)$ \\
\hline
\end{tabular}

Figure 4. ORTEP of $[(\pi$-allyl)palladium(2-di-tert-butylphosphinobiphenyl $)]\left[\mathrm{B}\left(\mathrm{Ar}_{\mathrm{F}}\right)_{4}\right], \mathbf{5}$. Counteranion, hydrogen atoms, and $0.5 \mathrm{CH}_{2} \mathrm{Cl}_{2}$ omitted for clarity. Ellipsoids are drawn at $50 \%$.

Table 5. Selected bond lengths for complex 5.

\begin{tabular}{|c|c|}
\hline Bond & Bond Length $(\AA)$ \\
\hline Pd1-C1 & $2.248(3)$ \\
\hline Pd1-C2 & $2.170(3)$ \\
\hline Pd1-C3 & $2.109(3)$ \\
\hline Pd1-C9 & $2.357(3)$ \\
\hline Pd1-C4 & $2.525(3)$ \\
\hline Pd1-C 8 & $2.880(3)$ \\
\hline Pd1-P1 & $2.320(9)$ \\
\hline C8-C9 & $1.416(4)$ \\
\hline C4-C9 & $1.403(4)$ \\
\hline C1-C2 & $1.365(5)$ \\
\hline C2-C3 & $1.389(4)$ \\
\hline
\end{tabular}

Figure 5. ORTEP of [( $\pi$-allyl)palladium(2-di-tert-butylphosphino-2'-methylbiphenyl)][B( $\left.\left(\mathrm{Ar}_{\mathrm{F}}\right)_{4}\right]$ 6. Counteranion and hydrogen atoms are omitted for clarity. Ellipsoids are drawn at $50 \%$. 
Table 6. Select bond lengths for complex 6.

\section{Conclusion}

\begin{tabular}{|c|c|}
\hline Bond & Bond Length $(\AA)$ \\
\hline $\mathrm{Pd} 1-\mathrm{C} 1$ & $2.249(6)$ \\
\hline $\mathrm{Pd} 1-\mathrm{C} 2$ & $2.161(8)$ \\
\hline $\mathrm{Pd} 1-\mathrm{C} 3$ & $2.127(4)$ \\
\hline $\mathrm{Pd} 1-\mathrm{C} 4$ & $2.425(3)$ \\
\hline $\mathrm{Pd} 1-\mathrm{C} 5$ & $2.392(4)$ \\
\hline $\mathrm{Pd} 1-\mathrm{P} 1$ & $2.391(1)$ \\
\hline $\mathrm{C} 5-\mathrm{C} 4$ & $1.418(5)$ \\
\hline $\mathrm{C} 1-\mathrm{C} 2$ & $1.312(7)$ \\
\hline $\mathrm{C} 2-\mathrm{C} 3$ & $1.395(8)$ \\
\hline
\end{tabular}

Synthesis and characterization of neutral and cation ( $\pi$-allyl)palladium complexes containing dialkylbiaryl phosphine ligands has been described. Coordination of the lower pendent arene ring to palladium exists in solution and in the solid state. The palladium to metal interaction is not readily displaced in solution and implies a strong metal to arene interaction exists. Work evaluating the insertion chemistry of norbornene and $\alpha$-olefins with cationic complexes 1-6 and coupling reactions with 1a-6a are currently being explored.

\section{Experimental Section}

General Considerations. Unless noted, all procedures were conducted using standard inert atmosphere techniques in an argon filled glovebox or on a Schlenk line. ${ }^{1} \mathrm{H},{ }^{31} \mathrm{P}$, and ${ }^{13} \mathrm{C}$ NMR spectra were recorded on a Bruker AVIII $400 \mathrm{MHz}$ NMR spectrometer. Chloroform- $d$ and dichloromethane- $d_{2}$ were purchased from Cambridge Isotope Labs and dried over $\mathrm{CaH}_{2}$. Chemical shifts are referenced to residual $\mathrm{CHCl}_{3}\left(\delta 7.24\right.$ for $\left.{ }^{1} \mathrm{H}\right), \mathrm{CH}(\mathrm{D}) \mathrm{Cl}_{2}(\delta 5.32$ for $1 \mathrm{H})$, ${ }^{13} \mathrm{CDCl}_{3}\left(\delta 77.0\right.$ for $\left.{ }^{13} \mathrm{C}\right)$ and $\mathrm{H}_{3} \mathrm{PO}_{4}\left(\delta=0.00\right.$ for $\left.{ }^{31} \mathrm{P}\right)$. Elemental analyses were performed by Intertek Pharmaceutical Services of Whitehouse, NJ.

Materials. All solvents were dried and deoxygenated via three freeze-pump-thaw cycles prior to use. Diethyl ether was dried by passage though columns of activated alumina.[23] 
Dichloromethane and pentane were dried over $\mathrm{CaH}_{2}$. All phosphine ligands were purchased from Strem or Sigma Aldrich and used as received. $\mathrm{Na}_{2} \mathrm{PdCl}_{4}$ was purchased from Pressure Chemical and used as received. Hexanes, diethyl ether, dichloromethane, and acetonitrile were purchased from Aldrich. $\mathrm{NaB}\left(\mathrm{Ar}_{\mathrm{F}}\right)_{4}$ was synthesized using literature methods.[24] The ( $\pi$-allyl)palladium chloride dimer, $\left(\eta^{3}-\mathrm{C}_{3} \mathrm{H}_{5}\right)_{2} \mathrm{Pd}_{2} \mathrm{Cl}_{2}$, was purchased from Strem. ( $\pi$-Allyl)palladium bromide dimer, $\left(\eta^{3}-\mathrm{C}_{3} \mathrm{H}_{5}\right)_{2} \mathrm{Pd}_{2} \mathrm{Br}_{2}$, was synthesized according to literature methods.[25]

\section{Synthesis of ( $\pi$-Allyl)palladium(II) halide complexes}

( $\pi$-Allyl)palladium(2-(dicyclohexylphosphino-2',4',6'-tri-isopropyl)biphenyl)chloride (1a).

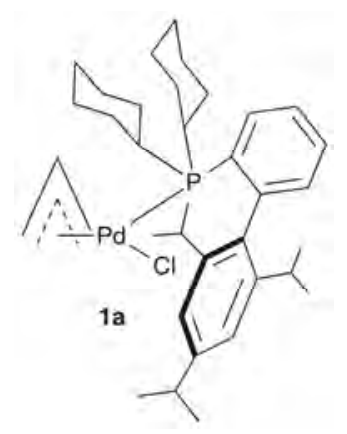

This complex was synthesized using an adapted literature procedure.[19] Very recently this complex was reported via a different synthesis.[14] A Schlenk flask was charged with ( $\pi$-allyl) palladium chloride dimer $(0.10 \mathrm{~g}, 0.27 \mathrm{mmol})$ and dicyclohexylphosphino-2',4',6'-triisopropyl)biphenyl $(0.21 \mathrm{~g}, 0.44 \mathrm{mmol})$. The reaction was carried out in ether $(10 \mathrm{~mL})$. The resulting product was filtered and washed with hexanes and ether in air. The isolated product was light yellow $(0.16 \mathrm{~g}, 53 \%) .{ }^{1} \mathrm{H}$ NMR $\left(400 \mathrm{MHz}, \mathrm{CDCl}_{3}, 25^{\circ} \mathrm{C}\right): \delta 7.89(\mathrm{br} \mathrm{m}, 1 \mathrm{H}, \mathrm{Ar}), 7.33(\mathrm{~m}$, $2 \mathrm{H}, \mathrm{Ar}), 7.03$ (m, 3H, Ar), 5.33 (br m, $1 \mathrm{H}$, allyl), 4.53 (t, $J=7.1 \mathrm{~Hz}, 1 \mathrm{H}$, allyl), 3.49 (dd, $J_{H-H}=$ $13.4 \mathrm{~Hz}, J_{\mathrm{H}-\mathrm{P}}=9.3 \mathrm{~Hz}, 1 \mathrm{H}$, allyl), 3.00 (br s, $1 \mathrm{H}$ ), 2.90 (heptet, $J=6.9 \mathrm{~Hz}, 1 \mathrm{H},{ }^{i} \operatorname{Pr}$ methine), 2.58 (br s, 1H), 2.45 (br s, 1H), 2.24 (br m, 3H), 1.80-0.81 (m, 22H, Cy), 1.26 (d, J=6.9 Hz, 12H, $\left.{ }^{i} \operatorname{Pr}\right), 0.93(\mathrm{~d}, J=6.6 \mathrm{~Hz}, 6 \mathrm{H}) .{ }^{13} \mathrm{C}\left\{{ }^{1} \mathrm{H}\right\} \mathrm{NMR}\left(100 \mathrm{MHz}, \mathrm{CDCl}_{3}, 25^{\circ} \mathrm{C}\right): \delta 149.0(\mathrm{~s}), 146.4(\mathrm{~s})$, $142.3(\mathrm{~s}), 136.8(\mathrm{~d}, J=21.5 \mathrm{~Hz}), 136.6(\mathrm{~s}), 134.0(\mathrm{~d}, J=5.8 \mathrm{~Hz}), 132.1(\mathrm{~d}, J=25.5 \mathrm{~Hz}), 128.2$ (s), $125.6(\mathrm{~d}, J=12.3 \mathrm{~Hz}), 121.0(\mathrm{~s}), 116.3(\mathrm{~d}, J=4.8 \mathrm{~Hz}), 79.5(\mathrm{~d}, J=29.3 \mathrm{~Hz}), 55.8(\mathrm{~s}), 34.7$ (br s), 34.4 (s), 34.2 (br s), 31.6 (br s), 30.7 (s), 29.3 (br s), 27.3 (d, $J=11.5 \mathrm{~Hz}$ ), 27.0 (d, $J=$ $12.1 \mathrm{~Hz}$ ), 26.0 (s), 25.8 (s), 24.1 (s), $22.5(\mathrm{~s}) .{ }^{31} \mathrm{P}\left\{{ }^{1} \mathrm{H}\right\} \mathrm{NMR}\left(122 \mathrm{MHz}, \mathrm{CDCl}_{3}, 25^{\circ} \mathrm{C}\right): \delta 48.4(\mathrm{br}$ s). Anal. Calcd for $\mathrm{C}_{36} \mathrm{H}_{54} \mathrm{PdPCl}$ : C, 65.55; H, 8.25. Found: C, 64.86; H, 7.86.

( $\pi$-Allyl)palladium(2-dicyclohexylphosphino-2',6'-dimethoxybiphenyl)bromide (2a). 


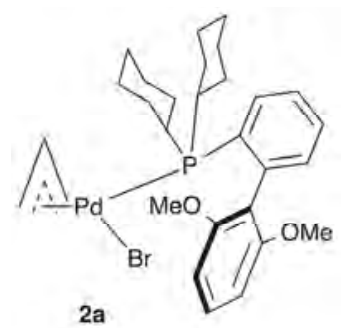

This complex was prepared using the procedure described for 1a using the ( $\pi$-allyl)palladium bromide dimer $(0.10 \mathrm{~g}, 0.27 \mathrm{mmol})$ and dicyclohexylphosphino-2',6'-dimethoxybiphenyl $(0.18 \mathrm{~g}$, $0.44 \mathrm{mmol})$. A light yellow product of $2 \mathrm{a}$ was isolated $(0.12 \mathrm{~g}, 42 \%)$. ${ }^{1} \mathrm{H}$ NMR $(400 \mathrm{MHz}$, $\left.\mathrm{CDCl}_{3}, 25^{\circ} \mathrm{C}\right): \delta 7.65(\mathrm{t}, J=8.8 \mathrm{~Hz}, 1 \mathrm{H}, \mathrm{Ar}), 7.37(\mathrm{t}, J=7.6 \mathrm{~Hz}, 1 \mathrm{H}, \mathrm{Ar}), 7.31(\mathrm{~m}, 2 \mathrm{H}, \mathrm{Ar}) 7.02$ (m, 1H, Ar), $6.58(\mathrm{~d}, J=7.6 \mathrm{~Hz}, 1 \mathrm{H}, \mathrm{Ar}), 6.51$ (roofed d, $J=7.5,1 \mathrm{H}$, Ar), 5.08 (m, 1H, allyl), 4.50 (t, 1H, J=7.1 Hz, allyl), 3.70 (s, 3H, OMe), 3.64 (s, 3H, OMe), 3.45 (br s, 1H, allyl), 3.06 $\left(\mathrm{dd}, J_{\mathrm{H}-\mathrm{H}}=13.7 \mathrm{~Hz}, J_{\mathrm{H}-\mathrm{P}}=9.2 \mathrm{~Hz}, 1 \mathrm{H}\right.$, allyl), 2.30 (br s, 2H, allyl, overlapping with Cy H), 2.16 (br m, 1H, Cy), 1.95 (br s, 1H, Cy), 1.94 (br s, 1H, Cy), 1.85 (br s, 1H, Cy), 1.64 (br s, 8H, Cy), 1.44 (br s, 2H, Cy) 1.17 (m, 8H, Cy). ${ }^{13} \mathrm{C}\left\{{ }^{1} \mathrm{H}\right\} \mathrm{NMR}\left(100 \mathrm{MHz}, \mathrm{CDCl}_{3}, 25^{\circ} \mathrm{C}\right): \delta 158.0(\mathrm{~d}, J=$ $25.5 \mathrm{~Hz}), 140.1(\mathrm{~s}), 135.7$ (d, $J=11.6 \mathrm{~Hz}), 133.1(\mathrm{~d}, J=5.2 \mathrm{~Hz}), 131.5(\mathrm{~d}, J=29.4 \mathrm{~Hz}), 129.5$ (s), 129.2 (s), 125.9 (d, $J=8.8 \mathrm{~Hz}), 119.6$ (s), 115.7 (s), 103.9 (s), 103.5 (s), 80.3 (d, J= 29.9 $\mathrm{Hz}), 58.5$ (s), 55.5 (s), 35.8 (t, $J=17.4 \mathrm{~Hz}), 29.8(\mathrm{~d}, J=19.6 \mathrm{~Hz}), 27.4$ (br s), 26.3 (s). ${ }^{31} \mathrm{P}\left\{{ }^{1} \mathrm{H}\right\}$ NMR (122 MHz, $\mathrm{CD}_{2} \mathrm{Cl}_{2}, 25^{\circ} \mathrm{C}$ ): $\delta$ 35.2. Anal. Calcd for $\mathrm{C}_{29} \mathrm{H}_{40} \mathrm{O}_{2} \mathrm{PdPBr}: \mathrm{C}, 54.60 ; \mathrm{H}, 6.32$. Found: C, 55.50; H, 6.18.

\section{( $\pi$-Allyl)palladium(2-dicylohexylphosphinobiphenyl)bromide (3a).}

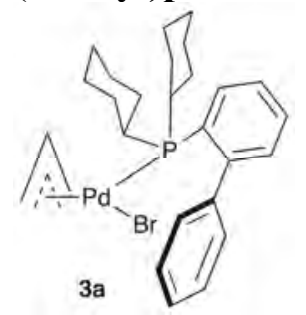

This chloride version of this complex was previously reported by Widenhoefer.[4] The complex was prepared using the procedure described for 1a using the ( $\pi$-allyl)palladium bromide dimer (0.10 g, $0.27 \mathrm{mmol})$ and 2-dicyclohexylphosphinobiphenyl $(0.15 \mathrm{~g}, 0.44 \mathrm{mmol})$. A light yellow product formed yielding $3 \mathbf{a}(0.13 \mathrm{~g}, 51 \%)$. ${ }^{1} \mathrm{H} \mathrm{NMR}\left(400 \mathrm{MHz}, \mathrm{CDCl}_{3}, 25^{\circ} \mathrm{C}\right): \delta 7.64(\mathrm{t}, \mathrm{J}=9.0$ $\mathrm{Hz}, 1 \mathrm{H}, \mathrm{Ar}), 7.48$ (m, 2H, Ar), 7.35 (m, 4H, Ar), 7.26 (m, 2H, Ar), 4.75 (m, 1H, allyl), 4.43 (t, J $=6.2 \mathrm{~Hz}, 1 \mathrm{H}$, allyl), $3.29(\mathrm{~d}, J=5.7,1 \mathrm{H}$, allyl), 3.07 (dd, $J=13.7 \mathrm{~Hz}, J=9.4 \mathrm{~Hz}, 1 \mathrm{H}$, allyl), 2.32 (br m, 2H, Cy), 2.06 (br m, 1H, Cy), 1.99 (br m, 1H, Cy), 1.82 (d, J=12.6 Hz, 1H, allyl), 1.74 (m, 8H, Cy), 1.40 (m, 2H, Cy), 1.18 (m, 8 H, Cy). ${ }^{13} \mathrm{C}\left\{{ }^{1} \mathrm{H}\right\}$ NMR $\left(100 \mathrm{MHz}, \mathrm{CDCl}_{3}, 25^{\circ} \mathrm{C}\right): \delta$ 147.9 (d, $J=11.0 \mathrm{~Hz}), 142.1$ (br s), 134.5 (d, $J=5.8 \mathrm{~Hz}), 133.0$ (d, $J=6.6 \mathrm{~Hz}), 130.0$ (s), 129.9 (s), 128.5 (s), 128.2 (d, $J=27.2 \mathrm{~Hz}), 127.3(\mathrm{~s}), 126.7$ (d, $J=6.7 \mathrm{~Hz}), 114.8$ (d, $J=5.1 \mathrm{~Hz}), 57.8$ (s), $36.8(\mathrm{~d}, J=20.0 \mathrm{~Hz}), 36.4(\mathrm{~d}, J=36.4 \mathrm{~Hz}), 30.4(\mathrm{~s}), 29.9$ (s), $29.4(\mathrm{~s}), 29.1$ (s), $27.3(\mathrm{~m})$, 26.3 (s). ${ }^{31} \mathrm{P}\left\{{ }^{1} \mathrm{H}\right\}$ NMR $\left(122 \mathrm{MHz}, \mathrm{CDCl}_{3}, 25^{\circ} \mathrm{C}\right): \delta 28.7$ (s). Anal. Calcd for $\mathrm{C}_{27} \mathrm{H}_{36} \mathrm{PdPBr}: \mathrm{C}$, 56.12; H, 6.28. Found: C, 56.00; H, 5.86.

( $\pi$-Allyl)palladium(2-dicyclohexylphosphino-2'methylbiphenyl)bromide (4a). 


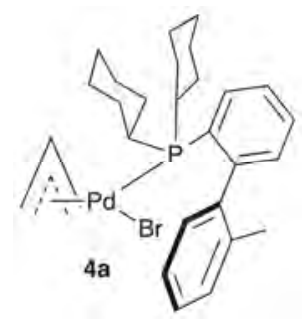

The complex was prepared using the procedure described for 1a using the ( $\pi$-allyl)palladium bromide dimer $(0.10 \mathrm{~g}, 0.27 \mathrm{mmol})$ and dicyclohexylphosphino-2'-methylbiphenyl $(0.16 \mathrm{~g}, 0.44$ mmol). A light yellow product formed yielding $4 \mathbf{a}(0.092 \mathrm{~g}, 37 \%)$. Two rotamers are observed by NMR spectroscopy in approximately a 1:1 ratio. ${ }^{1} \mathrm{H}$ NMR $\left(400 \mathrm{MHz}, \mathrm{CDCl}_{3}, 25^{\circ} \mathrm{C}\right): \delta 7.71$ (br t, 1H, Ar), 7.64 (br t, 1H, Ar), 7.46 (br s, 1H, Ar), 7.38 (m, 4H, Ar), 7.21 (m, 5H, Ar), 7.17 (br m, 2H, Ar), 7.10 (br m, 2H, Ar), 5.17 (br m, 1H, allyl), 4.87 (br m, 1H, allyl), 4.49 (br m, 2H, allyl), 3.29 (m, 2H, allyl), $3.22(\mathrm{t}, J=12.6 \mathrm{~Hz}, 1 \mathrm{H}$, allyl), 2.95 (t, $J=12.6 \mathrm{~Hz}, 1 \mathrm{H}$, allyl), 2.39 (m, 1H, Cy), 2.28 (m, 1H, Cy), 2.10 (s, 3H, Me), 2.03 (s, 3H, Me), 2.08 (overlapping m, 2H, Cy), 1.93 (m, 2H, Cy), 1.67 (br m, 18 H, Cy), 1.18 (m, 18 H, Cy), 0.97 (m, 2H, Cy). ${ }^{13} \mathrm{C}\left\{{ }^{1} \mathrm{H}\right\} \mathrm{NMR}$ $\left(100 \mathrm{MHz}, \mathrm{CDCl}_{3}, 25^{\circ} \mathrm{C}\right): \delta 146.3(\mathrm{~m}), 146.1(\mathrm{~m}), 141.7$ (s), $141.4(\mathrm{~s}), 136.7$ (s), $136.3(\mathrm{~s}), 135.2$ (br d), 134.9 (br d), 132.6 (s), 132.5 (s), 130.8 (s), 130.5 (d, J=12.0 Hz), 129.5 (s), 129.1 (br d, overlapping), 128.9 (br d, overlapping) 128.7, 127.9 (s), 127.7 (s), 126.6 (br s), 126.2 (s), 125.2 (s), $116.0(\mathrm{~s}), 115.0(\mathrm{~s}), 79.5(\mathrm{~d}, J=28.2 \mathrm{~Hz}), 79.1(\mathrm{~d}, J=30.6 \mathrm{~Hz}), 58.2(\mathrm{~s}), 57.7(\mathrm{~s}), 36.8(\mathrm{~m})$, $35.9(\mathrm{~d}, J=35.9 \mathrm{~Hz}), 30.8(\mathrm{~s}), 30.1$ (d, $J=14.6 \mathrm{~Hz}), 29.7$ (d, $J=11.1 \mathrm{~Hz}), 29.5$ (d, $J=6.4 \mathrm{~Hz})$, 27.5 (s, overlapping), 27.4 (s, overlapping), 27.2 (s), 27.1 (s), 26.4 (s), 26.1 (s), 21.7 (s), 21.2 (s). ${ }^{31} \mathrm{P}\left\{{ }^{1} \mathrm{H}\right\}$ NMR $\left(122 \mathrm{MHz}, \mathrm{CDCl}_{3}, 25^{\circ} \mathrm{C}\right): \delta 34.1$ (s), 31.0 (s). Anal. Calcd for $\mathrm{C}_{28} \mathrm{H}_{38} \mathrm{PdPBr}$ : C, 56.36; H, 5.84. Found: C, 56.82; H, 6.47.

\section{( $\pi$-Allyl)palladium(2-di-'butylphosphinobiphenyl)bromide (5a).}

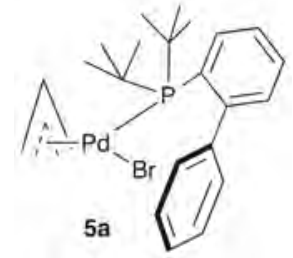

The chloride version of this complex was reported by Widenhoefer.[4] The complex was prepared using the procedure described for 1a using the ( $\pi$-allyl)palladium bromide dimer $(0.10$ $\mathrm{g}, 0.27 \mathrm{mmol})$ and di- ${ }^{t}$ butylphosphinobiphenyl $(0.13 \mathrm{~g}, 0.44 \mathrm{mmol})$. A light yellow product of 5a was afforded $(0.18 \mathrm{~g}, 76 \%)$. ${ }^{1} \mathrm{H}$ NMR $\left(400 \mathrm{MHz}, \mathrm{CDCl}_{3}, 25^{\circ} \mathrm{C}\right): \delta 7.95(\mathrm{t}, J=6.7 \mathrm{~Hz}, 1 \mathrm{H}, \mathrm{Ar})$, 7.62 (br d, $J=7.0 \mathrm{~Hz}, 2 \mathrm{H}, \mathrm{Ar}), 7.43$ (t, $J=7.4 \mathrm{~Hz}, 1 \mathrm{H}, \mathrm{Ar}), 7.36$ (m, 3H, Ar), 7.27 (m, 2H, Ar), 4.51 (br m, 1H, allyl), 4.05 (br m, 2H, allyl), 2.53 (br m, 1H, allyl), 1.46 (d, J=13.4 Hz, 18H, $\left.{ }^{t} \mathrm{Bu}\right) .{ }^{13} \mathrm{C}\left\{{ }^{1} \mathrm{H}\right\} \mathrm{NMR}\left(100 \mathrm{MHz}, \mathrm{CDCl}_{3}, 25^{\circ} \mathrm{C}\right): \delta 149.2(\mathrm{~d}, J=16.3 \mathrm{~Hz}), 142.3(\mathrm{~d}, J=4.8 \mathrm{~Hz})$, $135.4(\mathrm{~s}), 134.2$ (d, $J=7.0), 130.6$ (s), 130.2 (d, $J=19.4 \mathrm{~Hz}), 130.1$ (s), 128.7 (s), 126.8 (s), $125.6(\mathrm{~d}, J=4.0 \mathrm{~Hz}), 113.0(\mathrm{~s}), 37.7(\mathrm{~d}, J=9.9 \mathrm{~Hz}), 31.4(\mathrm{~s})$. Carbons for allyl group could not be located at this temperature. ${ }^{31} \mathrm{P}\left\{{ }^{1} \mathrm{H}\right\} \mathrm{NMR}\left(122 \mathrm{MHz}, \mathrm{CDCl}_{3}, 25^{\circ} \mathrm{C}\right): \delta 55.4$ (s). Anal. Calcd for $\mathrm{C}_{23} \mathrm{H}_{32} \mathrm{PdPBr}$ : C, 52.54; H, 6.13. Found: $\mathrm{C}, 52.43 ; \mathrm{H}, 6.02$.

( $\pi$-Allyl)palladium(2-di-'butylphosphino-2'-methylbiphenyl)bromide (6a). 


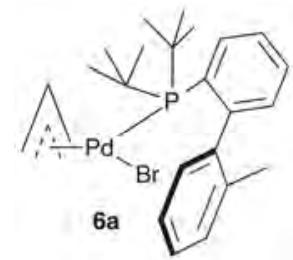

The complex was prepared using the procedure described for 1a using the ( $\pi$-allyl)palladium bromide dimer $(0.10 \mathrm{~g}, 0.27 \mathrm{mmol})$ and di-'butylphosphino-2'-methylbiphenyl $(0.14 \mathrm{~g}, 0.44$ mmol). A light yellow product of $6 \mathbf{a}$ was isolated $(0.13 \mathrm{~g}, 54 \%)$. ${ }^{1} \mathrm{H} \mathrm{NMR}\left(400 \mathrm{MHz}, \mathrm{CDCl}_{3}\right.$, $25^{\circ} \mathrm{C}$ ): $\delta 7.88(\mathrm{~m}, 1 \mathrm{H}, \mathrm{Ar}), 7.59$ (br s, $\left.1 \mathrm{H}, \mathrm{Ar}\right), 7.38(\mathrm{~m}, 2 \mathrm{H}, \mathrm{Ar}), 7.18(\mathrm{~m}, 3 \mathrm{H}, \mathrm{Ar}), 7.11(\mathrm{~m}, 1 \mathrm{H}$, Ar), 4.92 (br m, 1H, allyl), 4.13 (br m, 3H, allyl), 2.37 (br m, 1H, allyl), 2.05 (s, 3H, Me), 1.50 $(\mathrm{d}, J=13.6 \mathrm{~Hz}, 9 \mathrm{H}), 1.38(\mathrm{~d}, J=13.4 \mathrm{~Hz}, 9 \mathrm{H}) .{ }^{13} \mathrm{C}\left\{{ }^{1} \mathrm{H}\right\} \mathrm{NMR}\left(100 \mathrm{MHz}, \mathrm{CDCl}_{3}, 25^{\circ} \mathrm{C}\right): \delta 148.1$ (d, $J=17.4 \mathrm{~Hz}$ ), 141.5 (s), 137.3 (br s), 135.1 (s), 133.7 (d, $J=7.2 \mathrm{~Hz}$ ), 130.1 (s), 129.8 (s), 129.3 (s), 127.2 (s), 126. 3 (br s), 125.6 (d, $J=3.9 \mathrm{~Hz}), 113.4$ (s), 63.9 (br s), 37.8 (d, $J=10.4$ $\mathrm{Hz}), 37.0$ (s), 32.2 (d, $J=7.4 \mathrm{~Hz}), 30.5$ (d, $J=5.6 \mathrm{~Hz}), 22.0$ (br s). ${ }^{31} \mathrm{P}\left\{{ }^{1} \mathrm{H}\right\} \mathrm{NMR}(122 \mathrm{MHz}$, $\mathrm{CDCl}_{3}, 25^{\circ} \mathrm{C}$ ): $\delta 56.1$ (s). A suitable elemental analysis for $6 \mathbf{a}$ could not be obtained.

\section{Synthesis of Cationic ( $\pi$-Allyl)palladium Complexes Containing Bulky Dialkylbiaryl phosphine Ligands.}

\section{[( $\pi$-Allyl)palladium(2-(dicyclohexylphosphino-2',4',6'-tri-isopropyl)biphenyl)][B(Ar $\left.\left.{ }_{F}\right)_{4}\right]$} (1).

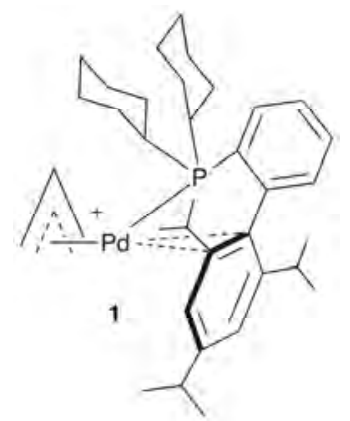

The complex was prepared using a modified literature procedure. ${ }^{1}$ A Schlenk flask was charged with complex 1a $(0.050 \mathrm{~g}, 0.076 \mathrm{mmol})$ and $\mathrm{NaB}\left(\mathrm{Ar}_{\mathrm{F}}\right)_{4}(0.067 \mathrm{~g}, 0.076 \mathrm{mmol})$. The compounds were dissolved in $\mathrm{CH}_{2} \mathrm{Cl}_{2}(5 \mathrm{~mL})$ and left to stir overnight. The product was filtered by cannula filtration. A light yellow product of 1 was afforded (0.062 g, $55 \%)$. ${ }^{1} \mathrm{H} \mathrm{NMR}\left(400 \mathrm{MHz}, \mathrm{CDCl}_{3}\right.$, $\left.25^{\circ} \mathrm{C}\right): \delta 7.67\left(\mathrm{~s}, 8 \mathrm{H}, \mathrm{Ar}_{\mathrm{F}}\right.$, overlapping $\left.1 \mathrm{H}\right), 7.49\left(\mathrm{~s}, 4 \mathrm{H}, \mathrm{Ar}_{\mathrm{F}}\right.$, overlapping $\left.3 \mathrm{H} \mathrm{Ar}\right), 7.34$ (br s, $1 \mathrm{H}$, Ar), 6.80 (br s, 1H, Ar), 5.31 (m, 1H, allyl), 3.92 (broad s, 1H, allyl), 3.55 (dd, $J=9.0 \mathrm{~Hz}, J=$ $14.1 \mathrm{~Hz}, 1 \mathrm{H}$, allyl), 2.99 (heptet, $J=7.0 \mathrm{~Hz}, 1 \mathrm{H},{ }^{i} \operatorname{Pr}$ methine), $2.51(\mathrm{~d}, J=12.4 \mathrm{~Hz}, 1 \mathrm{H}$, allyl, overlapping 1H), 2.33 (br, 2H, CH), 2.18-1.65 (br, 12H, Cy), 1.32-1.17 (br, 10H, overlapping iPr), $1.31\left(\mathrm{~d}, J=7.1 \mathrm{~Hz}, 6 \mathrm{H},{ }^{i} \operatorname{Pr} \mathrm{CH}_{3}\right), 1.24\left(\mathrm{~d}, J=6.8 \mathrm{~Hz}, 6 \mathrm{H},{ }^{i} \operatorname{Pr} \mathrm{CH}_{3}\right), 0.93(\mathrm{~d}, J=6.7 \mathrm{~Hz}, 3 \mathrm{H}$, $\left.{ }^{i} \operatorname{Pr} \mathrm{CH}_{3}\right), 0.90\left(\mathrm{~d}, J=6.7 \mathrm{~Hz}, 3 \mathrm{H},{ }^{i} \operatorname{Pr} \mathrm{CH}_{3}\right) .{ }^{13} \mathrm{C}\left\{{ }^{1} \mathrm{H}\right\} \mathrm{NMR}\left(100 \mathrm{MHz}, \mathrm{CDCl}_{3}, 25^{\circ} \mathrm{C}\right): \delta 161.9$ (q, $J=49.6 \mathrm{~Hz}, \mathrm{Ar}_{\mathrm{F}}$ ), 153.7 (br s), 149.9 (br s), 149.3 (br s), 145.1 (d, J=20.0 Hz), 135.1 (s, $\operatorname{Ar}_{\mathrm{F}}$ ), 133.0 (br s), 132.4 (br s), 129.2 (qq, $J=3.0 \mathrm{~Hz}, J=34.4 \mathrm{~Hz}, \operatorname{Ar}_{\mathrm{F}}$ ), 129.1 (s, overlapping $\operatorname{Ar}_{\mathrm{F}}$ ), 126.2 (s), 125.6 (br s, overlapping $\operatorname{Ar}_{\mathrm{F}}$ ), 123.5 (s, overlapping $\operatorname{Ar}_{\mathrm{F}}$ ), 122.1 (d, $J=271.0 \mathrm{~Hz}, \operatorname{Ar}_{\mathrm{F}}$ ), $119.3(\mathrm{~s}), 117.7$ (t, $J=3.9 \mathrm{~Hz}, \mathrm{Ar}_{\mathrm{F}}$ ), 101.4 (br s), 50.2 (br s), 38.2 (br s), 36.9 (br s), 34.3 (s), 32.3 (s), 31.2 (s), 30.9 (br s), 30.0 (s), 29.7 (s), 27.4 (d, J=12.3 Hz), 27.1 (d, J=12.4 Hz), 26.9 (br s), 
$25.8(\mathrm{~d}, J=10.7 \mathrm{~Hz}), 25.3(\mathrm{~d}, \mathrm{~J}=14.5 \mathrm{~Hz}), 24.9$ (br) 24.6 (s), 24.3 (s). ${ }^{31} \mathrm{P}\left\{{ }^{1} \mathrm{H}\right\} \mathrm{NMR}(122 \mathrm{MHz}$, $\mathrm{CDCl}_{3}, 25^{\circ} \mathrm{C}$ ): $\delta 47.6$ (s). Anal. Calcd for $\mathrm{C}_{68} \mathrm{H}_{66} \mathrm{~F}_{24} \mathrm{PdPB}: \mathrm{C}, 54.91 ; \mathrm{H}, 4.47$. Found: $\mathrm{C}, 54.75 ; \mathrm{H}$, 4.48 .

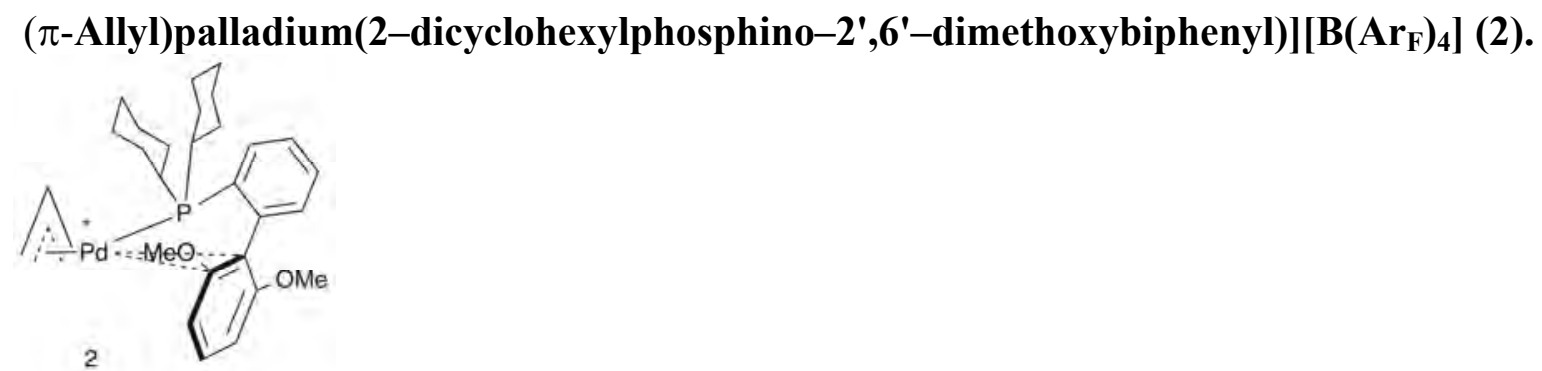

This complex was prepared using the procedure described for 1, using $(0.050 \mathrm{~g}, 0.079 \mathrm{mmol})$ of complex $2 \mathrm{a}$ and $\mathrm{NaB}\left(\mathrm{Ar}_{\mathrm{F}}\right)_{4}(0.069 \mathrm{~g}, 0.079 \mathrm{mmol})$. A light yellow product of 2 was isolated $(0.075 \mathrm{~g}, 67 \%) .{ }^{1} \mathrm{H}$ NMR $\left(400 \mathrm{MHz}, \mathrm{CD}_{2} \mathrm{Cl}_{2}, 25^{\circ} \mathrm{C}\right): \delta 7.72\left(\mathrm{~s}, 8 \mathrm{H}, \mathrm{Ar}_{\mathrm{F}}\right), 7.67(\mathrm{dt}, \mathrm{J}=6.9 \mathrm{~Hz}$, $2.3 \mathrm{~Hz}, 1 \mathrm{H}, \mathrm{Ar}), 7.56\left(\mathrm{~s}, 4 \mathrm{H}, \mathrm{Ar}_{\mathrm{F}}\right), 7.51(\mathrm{~m}, 2 \mathrm{H}, \mathrm{Ar}), 7.46$ (t, $\left.J=8.4 \mathrm{~Hz}, 1 \mathrm{H}, \mathrm{Ar}\right), 6.98(\mathrm{~d}, J=8.4$ $\mathrm{Hz}, 1 \mathrm{H}, \mathrm{Ar}), 6.86$ (d, $J=8.4 \mathrm{~Hz}, 1 \mathrm{H}, \mathrm{Ar}), 6.79(\mathrm{~m}, 1 \mathrm{H}, \mathrm{Ar}), 5.57$ (m, 1H, allyl), 3.95 (dd, $J=8.9$ $\mathrm{Hz}, J=14.2 \mathrm{~Hz}, 1 \mathrm{H}$, allyl), 3.86 (d, $J=6.0 \mathrm{~Hz}, 1 \mathrm{H}$, allyl), 3.78 (s, 3H, OMe), 3.69 (s, 3H, OMe), 2.63 (d, $J=12.2 \mathrm{~Hz}, 1 \mathrm{H}$, allyl), 2.48 (br t, 1H, allyl), 2.22 (m, 2H, Cy), 1.90-1.60 (m, 10H, Cy), 1.4-1.0 (m, 10H, Cy). ${ }^{13} \mathrm{C}\left\{{ }^{1} \mathrm{H}\right\} \operatorname{NMR}\left(100 \mathrm{MHz}, \mathrm{CD}_{2} \mathrm{Cl}_{2}, 25^{\circ} \mathrm{C}\right): \delta 162.3\left(\mathrm{q}, J=49.6 \mathrm{~Hz}, \mathrm{Ar}_{\mathrm{F}}\right)$, $144.2(\mathrm{~d}, J=22.7 \mathrm{~Hz}), 134.5(\mathrm{~s}), 135.4\left(\mathrm{~s}, \operatorname{Ar}_{\mathrm{F}}\right), 135.0(\mathrm{~s}), 133.1$ (d, $\left.J=2.1 \mathrm{~Hz}\right), 132.8(\mathrm{~s}), 132.0$ (s), 131.9 (s), 129.2 (qq, $J=3.0 \mathrm{~Hz}, J=34.4 \mathrm{~Hz}, \operatorname{Ar}_{\mathrm{F}}$ ), 129.3 (s), 129.0 (s), 128.9 (s), 125.2 (q, $J$ $\left.=270.8 \mathrm{~Hz}, \operatorname{Ar}_{\mathrm{F}}\right), 120.3(\mathrm{~d}, J=5.8 \mathrm{~Hz}), 118.0\left(\mathrm{br} \mathrm{t}, J=3.9 \mathrm{~Hz}, \operatorname{Ar}_{\mathrm{F}}\right), 106.4$ (d, $\left.J=18.7 \mathrm{~Hz}\right)$, $103.8(\mathrm{~d}, J=27.3 \mathrm{~Hz}), 101.6(\mathrm{~d}, J=4.0 \mathrm{~Hz}), 56.8$ (s, OMe), 56.7 (s, OMe), 49.1 (d, $J=2.6 \mathrm{~Hz})$, 36.9 (d, $J=24.0 \mathrm{~Hz}), 36.5$ (d, $J=24.2 \mathrm{~Hz}), 30.4(\mathrm{~d}, J=3.6 \mathrm{~Hz}), 30.1(\mathrm{~d}, J=3.5 \mathrm{~Hz}), 29.5(\mathrm{~s})$, $29.4(\mathrm{~s}), 27.4(\mathrm{~d}, J=4.3 \mathrm{~Hz}), 27.3(\mathrm{~d}, J=2.3 \mathrm{~Hz}), 27.3$ (s), 27.2 (d, $J=6.7 \mathrm{~Hz}), 26.4(\mathrm{~s}), 26.3(\mathrm{~s})$. ${ }^{31} \mathrm{P}\left\{{ }^{1} \mathrm{H}\right\}$ NMR $\left(122 \mathrm{MHz}, \mathrm{CD}_{2} \mathrm{Cl}_{2}, 25^{\circ} \mathrm{C}\right): \delta 52.8$ (s). Anal. Calcd for $\mathrm{C}_{61} \mathrm{H}_{52} \mathrm{~F}_{24} \mathrm{O}_{2} \mathrm{PdPB}$ : C, 51.55; H, 3.69. Found: C, 51.36; H, 3.43.

[( $\pi$-Allyl)palladium(2-dicyclohexylphosphinobiphenyl)][B(Ar$\left.)_{4}\right](3)$.

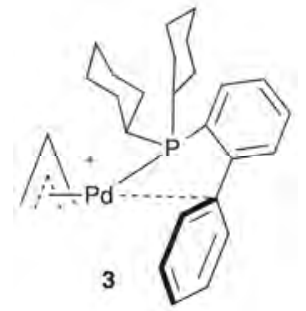

This complex was prepared using the procedure described for $\mathbf{1}$ using of the bromide complex 3a $(0.050 \mathrm{~g}, 0.087 \mathrm{mmol})$ and of $\mathrm{NaB}\left(\mathrm{Ar}_{\mathrm{F}}\right)_{4}(0.077 \mathrm{~g}, 0.087 \mathrm{mmol})$. A light yellow product was isolated $(0.75 \mathrm{~g}, 63 \%) .{ }^{1} \mathrm{H}$ NMR $\left(400 \mathrm{MHz}, \mathrm{CDCl}_{3}, 25^{\circ} \mathrm{C}\right): \delta 7.79$ (br t, $\left.2 \mathrm{H}, \mathrm{Ar}\right), 7.67(\mathrm{~s}, 8 \mathrm{H}$, $\left.\operatorname{Ar}_{\mathrm{F}}\right), 7.56(\mathrm{~m}, 3 \mathrm{H}, \mathrm{Ar}), 7.50\left(\mathrm{~s}, 4 \mathrm{H}, \mathrm{Ar}_{\mathrm{F}}\right), 7.34(\mathrm{t}, J=7.5 \mathrm{~Hz}, 1 \mathrm{H}, \mathrm{Ar}), 7.03(\mathrm{~m}, 3 \mathrm{H}, \mathrm{Ar}), 5.25(\mathrm{~m}$, $1 \mathrm{H}$, allyl), $3.75(\mathrm{~d}, J=6.8 \mathrm{~Hz}, 1 \mathrm{H}$, allyl), $3.44(\mathrm{dd}, J=9.1 \mathrm{~Hz}, J=14.2 \mathrm{~Hz}, 1 \mathrm{H}$, allyl), 3.27 (t, $J$ $=6.0 \mathrm{~Hz}, 1 \mathrm{H}$, allyl), 2.62 (d, $J=12.4 \mathrm{~Hz}, 1 \mathrm{H}$, allyl), 2.27 (br q, 1H, Cy), 2.15 (br q, 1H, Cy), 1.78 (br m, 10H, Cy), 1.27 (m, 6H, Cy), 1.07 (m, 3H, Cy), 0.85 (m, 1H, Cy). ${ }^{13} \mathrm{C}\left\{{ }^{1} \mathrm{H}\right\}$ NMR $(100$ $\left.\mathrm{MHz}, \mathrm{CDCl}_{3}, 25^{\circ} \mathrm{C}\right): \delta 161.8\left(\mathrm{q} J=49.6 \mathrm{~Hz}, \mathrm{Ar}_{\mathrm{F}}\right), 147.6(\mathrm{~d}, J=18.8 \mathrm{~Hz}), 138.8(\mathrm{~d}, J=4.8 \mathrm{~Hz})$, $135.1(\mathrm{~s}), 135.0\left(\mathrm{~s}, \mathrm{Ar}_{\mathrm{F}}\right), 132.7$ (d, $J=2.1 \mathrm{~Hz}$ ), 132.4 (s, overlapping), 132.4 (d, $J=9.3 \mathrm{~Hz}$, overlapping), 129.6 (s, two overlapping signals), 129.2 (qq, $J=3.0 \mathrm{~Hz}, J=34.4 \mathrm{~Hz}, \mathrm{Ar}_{\mathrm{F}}$ ), 127.3 
(s), $127.2\left(\mathrm{q}, J=270.9 \mathrm{~Hz}, \operatorname{Ar}_{\mathrm{F}}\right), 119.0(\mathrm{~d}, J=6.0 \mathrm{~Hz}), 117.7\left(\mathrm{t}, J=3.8 \mathrm{~Hz}, \operatorname{Ar}_{\mathrm{F}}\right), 99.1(\mathrm{~d}, J=$ $26.9 \mathrm{~Hz}), 53.7(\mathrm{~d}, J=5.1 \mathrm{~Hz}), 36.2(\mathrm{~d}, J=24.0 \mathrm{~Hz}), 35.6(\mathrm{~d}, J=24.2 \mathrm{~Hz}), 29.7$ (d, $J=3.7 \mathrm{~Hz})$, $29.4(\mathrm{~d}, J=3.2 \mathrm{~Hz}), 29.1$ (s) $26.8(\mathrm{~d}, J=2.9 \mathrm{~Hz}), 26.4(\mathrm{~s}), 26.5(\mathrm{~s}), 25.7(\mathrm{~d}, J=5.7 \mathrm{~Hz}) .{ }^{31} \mathrm{P}\left\{{ }^{1} \mathrm{H}\right\}$ NMR (122 MHz, $\left.\mathrm{CDCl}_{3}, 25^{\circ} \mathrm{C}\right): \delta 43.9$ (s). Anal. Calcd for $\mathrm{C}_{59} \mathrm{H}_{48} \mathrm{~F}_{24} \mathrm{PdPB}$ : C, 52.06; H, 3.55. Found: C, 52.00; H, 3.31.

\section{[( $\pi$-Allyl)palladium(2-dicyclohexylphosphino-2'methylbiphenyl)][B(ArF $\left.)_{4}\right](4)$.}

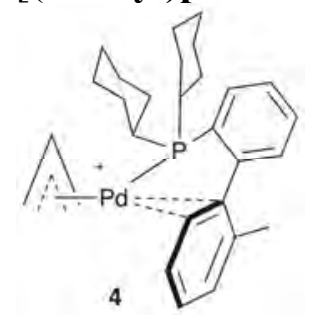

This complex was prepared using the procedure described for $\mathbf{1}$ using bromide complex 4a $(0.050 \mathrm{~g}, 0.084 \mathrm{mmol})$ and $\mathrm{NaB}\left(\mathrm{Ar}_{\mathrm{F}}\right)_{4}(0.074 \mathrm{~g}, 0.085 \mathrm{mmol})$. Complex 4 was afforded as a light yellow solid $(0.11 \mathrm{~g}, 92 \%)$. Two isomers of the complex are observed at room temperature on the NMR timescale. The ratio of the two isomers is $1: 1$ in solution. ${ }^{1} \mathrm{H} \mathrm{NMR}\left(400 \mathrm{MHz}, \mathrm{CDCl}_{3}\right.$, $\left.25^{\circ} \mathrm{C}\right): \delta 7.81(\mathrm{t}, J=7.1 \mathrm{~Hz}, 1 \mathrm{H}, \mathrm{Ar}), 7.68\left(\mathrm{~s}, 16 \mathrm{H}, \mathrm{Ar}_{\mathrm{F}}\right)$ overlapping $1 \mathrm{H} \mathrm{m}$ for Ar groups, 7.61 $(\mathrm{m}, 5 \mathrm{H}, \mathrm{Ar}), 7.52\left(\mathrm{~s}, 8 \mathrm{H}, \mathrm{Ar}_{\mathrm{F}}\right)$ overlapping $4 \mathrm{H} \mathrm{m}$ for Ar groups, $7.24(\mathrm{~m}, 2 \mathrm{H}, \mathrm{Ar})$ overlapping solvent residual, $6.93(\mathrm{~m}, 2 \mathrm{H}, \mathrm{Ar}), 6.67$ (d, J = 7.0 Hz, 1H, Ar), 6.56 (d, J=7.0 Hz, 1H, Ar), 5.48 (m, 1H, allyl), $5.16(\mathrm{~m}, 1 \mathrm{H}$, allyl), 3.90 (dd, $J=14.2 \mathrm{~Hz}, 9.3 \mathrm{~Hz}, 1 \mathrm{H}$, allyl), 3.84 (m, 1H, allyl), 3.27 (dd, J = 14.3 Hz, 9.2 Hz, 1H, allyl), 3.10 (t, $J=8.1 \mathrm{~Hz}, 1 \mathrm{H}$, allyl), 2.71 (br m, 2H, allyl), $2.43(\mathrm{~d}, \mathrm{~J}=12.2 \mathrm{~Hz}, 1 \mathrm{H}$, allyl) overlapping $1 \mathrm{H} \mathrm{m}$ for $\mathrm{Cy}, 2.33$ (d, J=12.1 Hz, 1H, allyl), 2.25 (s, $3 \mathrm{H}, \mathrm{Me}$ ), 2.19 (s, 3H, Me), 1.99-0.81 (br m, 44H). ${ }^{13} \mathrm{C}\left\{{ }^{1} \mathrm{H}\right\} \mathrm{NMR}\left(100 \mathrm{MHz}, \mathrm{CDCl}_{3}, 25^{\circ} \mathrm{C}\right): \delta$ 161.9 (q, $J=49.6 \mathrm{~Hz}), 147.3(\mathrm{~d}, J=20.8 \mathrm{~Hz}), 147.2$ (d, $J=19.8 \mathrm{~Hz}), 139.9$ (s), 139.5 (s), 135.3 (s), $135.0\left(\mathrm{~s}, \operatorname{Ar}_{\mathrm{F}}\right), 134.9(\mathrm{~s}), 134.0(\mathrm{~d}, J=4.7 \mathrm{~Hz}), 133.5(\mathrm{~s}), 133.4(\mathrm{~d}, J=5.0 \mathrm{~Hz}), 133.1$ (s), 132.9 (d, $J=2.3 \mathrm{~Hz}), 132.8$ (s, overlapping 1 signal), 132.7 (s), 132.2 (d, $J=10.1 \mathrm{~Hz}), 132.1$ (d, $J=10.1 \mathrm{~Hz}), 129.5(\mathrm{~d}, J=5.4 \mathrm{~Hz}), 129.4(\mathrm{~d}, J=5.4 \mathrm{~Hz}), 128.9(\mathrm{qq}, J=3.0 \mathrm{~Hz}, J=34.4 \mathrm{~Hz}$, $\left.\mathrm{Ar}_{\mathrm{F}}\right), 128.7(\mathrm{~s}), 128.6(\mathrm{~d}, J=38.7 \mathrm{~Hz}), 128.5(\mathrm{~s}), 127.9(\mathrm{~d}, J=38.0 \mathrm{~Hz}), 124.8(\mathrm{q}, J=271.2 \mathrm{~Hz}$, $\left.\operatorname{Ar}_{\mathrm{F}}\right), 120.7$ (overlapping $\left.\operatorname{Ar}_{\mathrm{F}} \mathrm{q}\right), 118.0(\mathrm{~d}, J=5.8 \mathrm{~Hz}), 117.7\left(\mathrm{t}, J=3.8 \mathrm{~Hz}, \operatorname{Ar}_{\mathrm{F}}\right), 112.4(\mathrm{~s}), 110.3$ (s), $102.6(\mathrm{~d}, J=27.0 \mathrm{~Hz}), 102.4(\mathrm{~d}, J=26.9 \mathrm{~Hz}), 51.6(\mathrm{br} \mathrm{t}), 37.6(\mathrm{~d}, J=23.6 \mathrm{~Hz}), 36.8(\mathrm{~d}, J=$ $24.1 \mathrm{~Hz}), 35.3(\mathrm{~d}, J=24.6 \mathrm{~Hz}), 34.8(\mathrm{~d}, J=24.7 \mathrm{~Hz}), 30.1-29.5$ (overlapping multiple signals), 28.3 (s), 28.3 (s), 28.2 (s), 27.2 (s), 27.1-26.4 (overlapping multiple signals), 25.8 (br s), 25.7 (br s), 20.9 (s), 20.8 (s). ${ }^{31} \mathrm{P}\left\{{ }^{1} \mathrm{H}\right\}$ NMR (122 MHz, $\left.\mathrm{CDCl}_{3}, 25^{\circ} \mathrm{C}\right): \delta 46.2$ (s), 45.1 (s). Anal. Calcd for $\mathrm{C}_{60} \mathrm{H}_{50} \mathrm{~F}_{24} \mathrm{PdPB}$ : C, 52.40; H, 3.66. Found: C, 52.44; H, 3.66.

\section{[( $\pi$-Allyl)palladium(2-di-tert-butylphosphinobiphenyl)][B( $\left.\left(\mathrm{Ar}_{\mathrm{F}}\right)_{4}\right](5)$.}

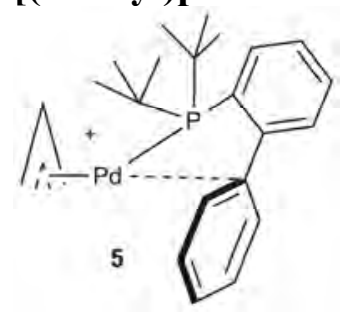

This complex was prepared using the procedure described for $\mathbf{1}$ using bromide complex 5a $(0.050 \mathrm{~g}, 0.095 \mathrm{mmol})$ and $\mathrm{NaB}\left(\mathrm{Ar}_{\mathrm{F}}\right)_{4}(0.084 \mathrm{~g}, 0.095 \mathrm{mmol})$. Complex $\mathbf{5}$ was isolated as a light 
yellow product $(0.088 \mathrm{~g}, 71 \%) .{ }^{1} \mathrm{H} \mathrm{NMR}\left(400 \mathrm{MHz}, \mathrm{CDCl}_{3}, 25^{\circ} \mathrm{C}\right): \delta 7.84(\mathrm{t}, J=6.5 \mathrm{~Hz}, 1 \mathrm{H}$, Ar), 7.75 (t, $J=7.7 \mathrm{~Hz}, 2 \mathrm{H}, \mathrm{Ar}), 7.67$ (s, 8H), 7.47 (m, 2H, Ar, overlapping), 7.40 (t, J = 7.6 Hz, 1H, Ar), 7.17 (br s, 2H, Ar), 6.80 (m, 1H, Ar), 5.39 (m, 1H, allyl), 4.25 (br s, 1H, allyl), 3.35 (br s, $1 \mathrm{H}$, allyl), 2.75 (br s, $1 \mathrm{H}$, allyl), 2.66 (br s, $1 \mathrm{H}$, allyl), $1.30(\mathrm{~d}, J=14.9 \mathrm{~Hz}, 18 \mathrm{H}) .{ }^{13} \mathrm{C}\left\{{ }^{1} \mathrm{H}\right\}$ NMR (100 MHz, $\left.\mathrm{CDCl}_{3}, 25^{\circ} \mathrm{C}\right): \delta 161.7\left(\mathrm{q}, J=49.7 \mathrm{~Hz}, \mathrm{Ar}_{\mathrm{F}}\right) 147.2(\mathrm{~d}, J=20.4 \mathrm{~Hz}), 134.8(\mathrm{~s}$, $\left.\operatorname{Ar}_{\mathrm{F}}\right), 134.1(\mathrm{~s}), 133.3(\mathrm{~d}, J=10.4 \mathrm{~Hz}), 132.1(\mathrm{~s}), 130.9(\mathrm{br} \mathrm{s}), 129.4$ (s, overlapping $\left.\operatorname{Ar}_{\mathrm{F}}\right), 129.2$ $\left(\mathrm{qq}, J=3.0 \mathrm{~Hz}, J=34.4 \mathrm{~Hz}, \operatorname{Ar}_{\mathrm{F}}\right.$ ), 129.1 (s, overlapping $\operatorname{Ar}_{\mathrm{F}}$ ), 128.7 (br s, overlapping $\operatorname{Ar}_{\mathrm{F}}$ ), $128.6(\mathrm{~s}), 128.5(\mathrm{~d}, J=4.6 \mathrm{~Hz}), 124.5\left(\mathrm{q}, J=270.9 \mathrm{~Hz}, \operatorname{Ar}_{\mathrm{F}}\right), 118.9(\mathrm{~d}, J=5.9 \mathrm{~Hz}), 117.5(\mathrm{t}, J=$ $3.8 \mathrm{~Hz}, \mathrm{Ar}_{\mathrm{F}}$ ), 101.3 (br s), 56.3 (br s), 37.4 (d, $\left.J=15.2 \mathrm{~Hz}\right), 30.5$ (s), 30.0 (s). ${ }^{31} \mathrm{P}\left\{{ }^{1} \mathrm{H}\right\} \mathrm{NMR}$ $\left(122 \mathrm{MHz}, \mathrm{CDCl}_{3}, 25^{\circ} \mathrm{C}\right.$ ): $\delta 72.8$ (s). Anal. Calcd for $\mathrm{C}_{55} \mathrm{H}_{44} \mathrm{~F}_{24} \mathrm{PdPB}$ : C, 50.46; H, 3.39. Found: C, 50.50; H, 3.07.

[( $\pi$-Allyl)palladium(2-di-tert-butylphosphino-2'-methylbiphenyl)][B( $\left.\left(\mathrm{Ar}_{\mathrm{F}}\right)_{4}\right](6)$.

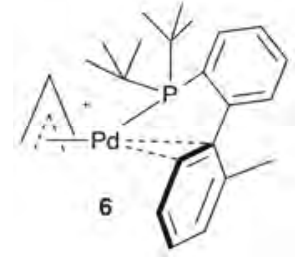

This complex was prepared using the procedure described for $\mathbf{1}$ using bromide complex $6 \mathbf{6}$ $(0.050 \mathrm{~g}, 0.093 \mathrm{mmol})$ and $\mathrm{NaB}\left(\mathrm{Ar}_{\mathrm{F}}\right)_{4}(0.082 \mathrm{~g}, 0.093 \mathrm{mmol})$. Complex 6 was afforded as a light yellow product $(0.077 \mathrm{~g}, 63 \%)$. Rotamers of this complex exist in solution; two sets of signals were observed, including individual ${ }^{31} \mathrm{P}$ resonances. The ratio of the two isomers at room temperature is 1 to $0.6 .{ }^{1} \mathrm{H} \mathrm{NMR}\left(400 \mathrm{MHz}, \mathrm{CDCl}_{3}, 25^{\circ} \mathrm{C}\right): \delta 7.86(\mathrm{~m}, 1.6 \mathrm{H}), 7.73(\mathrm{t}, \mathrm{J}=\mathrm{Hz}$, 0.6H, Ar), $7.67\left(13 \mathrm{H}, \mathrm{Ar}_{\mathrm{F}}\right), 7.62(\mathrm{~m}, 2 \mathrm{H}, \mathrm{Ar}), 7.50\left(\mathrm{~s}, 6.4 \mathrm{H}, \mathrm{Ar}_{\mathrm{F}}\right)$ overlapping 3.6H for $\mathrm{Ar}, 7.36$ $(\mathrm{dt}, J=7.6 \mathrm{~Hz}, 1.2 \mathrm{~Hz}, 0.6 \mathrm{H}, \mathrm{Ar}), 7.31$ (dt, $J=7.6 \mathrm{~Hz}, 1.2 \mathrm{~Hz}, 1 \mathrm{H}, \mathrm{Ar}), 6.92$ (d, $J=7.0 \mathrm{~Hz}$, $0.6 \mathrm{H}, \mathrm{Ar}), 6.76(\mathrm{~m}, 1.6 \mathrm{H}, \mathrm{Ar}), 6.60(\mathrm{~d}, J=7.0 \mathrm{~Hz}, 1 \mathrm{H}, \mathrm{Ar}), 5.50(\mathrm{~m}, 1 \mathrm{H}$, allyl), 5.21 (m, 0.6H, allyl), 4.26 (dt, $J=6.4 \mathrm{~Hz}, 2.1 \mathrm{~Hz}, 0.6 \mathrm{H}$, allyl), 4.16 (dt, J = 6.6 Hz, $2.2 \mathrm{~Hz}, 1 \mathrm{H}$, allyl), 3.71 (dd, $J=13.8 \mathrm{~Hz}, 9.2 \mathrm{~Hz}, 0.6 \mathrm{H}$, allyl), 3.47 (dd, $J=14.2 \mathrm{~Hz}, 9.1 \mathrm{~Hz}, 1 \mathrm{H}$, allyl), 2.68 (d, $J=12.4 \mathrm{~Hz}$, 0.6H, allyl), 2.60 (m, 2H, allyl), $2.30(\mathrm{~m}, 0.6 \mathrm{H}), 2.29$ (s, 3H, Me), $2.16(\mathrm{~s}, 1.8 \mathrm{H}, \mathrm{Me}), 1.40$ (d, J $\left.=15.2 \mathrm{~Hz}, 5.4 \mathrm{H},{ }^{t} \mathrm{Bu}\right), 1.33\left(\mathrm{~d}, J=6.4 \mathrm{~Hz}, 9 \mathrm{H},{ }^{t} \mathrm{Bu}\right), 1.29\left(\mathrm{~d}, J=6.4 \mathrm{~Hz}, 9 \mathrm{H},{ }^{t} \mathrm{Bu}\right), 1.23(\mathrm{~d}, J=$ $\left.14.9 \mathrm{~Hz}, 5.4 \mathrm{H},{ }^{t} \mathrm{Bu}\right) .{ }^{13} \mathrm{C}\left\{{ }^{1} \mathrm{H}\right\} \operatorname{NMR}\left(100 \mathrm{MHz}, \mathrm{CDCl}_{3}, 25^{\circ} \mathrm{C}\right): \delta 161.9\left(\mathrm{q}, J=49.6 \mathrm{~Hz}, \mathrm{Ar}_{\mathrm{F}}\right)$, 147.2 (d, $J=21.1 \mathrm{~Hz}$, major), 147.1 (d, $J=20.3 \mathrm{~Hz}), 142.3(\mathrm{~s}), 141.7(\mathrm{~s}), 135.0\left(\mathrm{~s}, \operatorname{Ar}_{\mathrm{F}}\right), 134.8$ (s), 134.7 (s), 134.4 (s), 133.1 (s), 133.0 (s), 133.0 (s), 132.9 (s), 132.7 (s), 132.6 (br s), 130.6 (d, $J=32.6 \mathrm{~Hz}), 130.4(\mathrm{~d}, J=31.9 \mathrm{~Hz}), 129.9(\mathrm{~s}), 129.8(\mathrm{~s}), 129.2(\mathrm{qq}, J=3.0 \mathrm{~Hz}, J=34.4 \mathrm{~Hz}$, $\left.\mathrm{Ar}_{\mathrm{F}}\right), 128.8(\mathrm{~s}), 128.7(\mathrm{~s}), 128.5(\mathrm{~s}), 128.5(\mathrm{~s}), 124.8\left(\mathrm{q}, J=270.9 \mathrm{~Hz}, \mathrm{Ar}_{\mathrm{F}}\right), 120.5(\mathrm{~s}), 120.4(\mathrm{~s})$, 117.7 (br t, $J=3.8 \mathrm{~Hz}, \operatorname{Ar}_{\mathrm{F}}$ ), $116.8(\mathrm{~s}), 115.6(\mathrm{~s}), 105.4$ (d, $\left.J=26.3 \mathrm{~Hz}\right), 103.0$ (d, $J=27.0 \mathrm{~Hz}$ ), $54.6(\mathrm{~d}, J=3.2 \mathrm{~Hz}), 54.4(\mathrm{~d}, J=3.2 \mathrm{~Hz}), 38.0(\mathrm{~d}, J=13.1 \mathrm{~Hz}), 37.8(\mathrm{~d}, J=11.6 \mathrm{~Hz}), 31.1(\mathrm{~d}, J=$ $5.4 \mathrm{~Hz}), 30.9(\mathrm{~d}, J=5.6 \mathrm{~Hz}), 30.5(\mathrm{~d}, J=5.3 \mathrm{~Hz}), 30.2(\mathrm{~d}, J=5.5 \mathrm{~Hz}), 21.1(\mathrm{~s}), 21.0(\mathrm{~s}) .{ }^{31} \mathrm{P}\left\{{ }^{1} \mathrm{H}\right\}$ NMR (122 MHz, $\mathrm{CDCl}_{3}, 25^{\circ} \mathrm{C}$ ): $\delta 75.0$ (s), 72.5 (s). Anal. Calcd for $\mathrm{C}_{56} \mathrm{H}_{46} \mathrm{~F}_{24} \mathrm{PdPB}: \mathrm{C}, 50.83$; H, 3.50. Found: C, 50.92; H, 3.14.

\section{X-ray Structure Analyses, Sample Preparation and Data Acquisition for 4a, 5a, 4, 5, and 6.}

Single crystals suitable for X-ray analysis were obtained by a layering saturated dichloromethane solutions of each complex with pentane at $-28^{\circ} \mathrm{C}$. Single crystals were selected for diffraction studies on a Bruker SMART Apex II diffractometer using Mo $\mathrm{K} \alpha$ radiation with a graphite 
monochromater.[26] Data was collected at 100(2) K. Crystals were corrected for absorption correction using SADABS.[27] Structures were solved by the use of direct methods.[28] Least squares refinement on $F^{2}$ was used for all reflections.[29] Structure solution, refinement, and the calculations of measurements were accomplished with the SHELXTL package.[30] Non hydrogen atoms were refined anisotropically. Hydrogen atoms were placed in idealized, theoretical positions.

In complexes $\mathbf{4 , 5}$, and $\mathbf{6}$, disorder in the fluorine atoms of the $\mathrm{B}\left(\mathrm{Ar}_{\mathrm{F}}\right)_{4}{ }^{-}$counteranion was evident. Attempts were made to model the positional disorder, but still resulted in larger than expected thermal ellipsoids. The disorder did not appear to affect the palladium complex of interest and were not modeled further. The $\pi$-allyl moieties in $\mathbf{4 a}, \mathbf{5 a}$, and $\mathbf{6}$ were modeled to account for disorder. When constraints were not used, anisotropic parameters diverged. In 4a and 6, the center carbon position was allowed to vary to locate the disordered position. In $\mathbf{6}$, the anisotropic parameter in the central carbon (C2A) diverged and modeled as isotropic only. In 5a, the terminal carbon atom positions were constrained while allowing the position of the center carbon to vary. The anisotropic thermal parameters were constrained for all three carbon atoms.

\section{Acknowledgements}

We thank Research Corporation for financial support through a Cottrell College Science Award. X-ray crystallography (\#0922931) and NMR data (\#1125993) were collected on instruments purchased through MRI grants from the National Science Foundation.

\section{Corresponding Author}

Email for A. R. O’C: oconnora@tcnj.edu

\section{References}

[1] J. Tsuji, Palladium Reagents and Catalysts: New Perspectives for the 21st Century, John Wiley \& Sons, Ltd, 2004.

[2] J. Lipian, R.A. Mimna, J.C. Fondran, D. Yandulov, R.A. Shick, B.L. Goodall, et al., Macromolecules 35 (2002) 8969-8977. doi:10.1021/ma0209287.

[3] D.P. Hruszkewycz, D. Balcells, L.M. Guard, N. Hazari, M. Tilset, J. Am. Chem. Soc. 136 (2014) 7300-7316. doi:10.1021/ja412565c.

[4] P. Kisanga, R.A. Widenhoefer, J. Am. Chem. Soc. 122 (2000) 10017-10026. doi:10.1021/ja001730+.

[5] A.R. O’Connor, W. Kaminsky, D.M. Heinekey, K.I. Goldberg, Organometallics 30 (2011) 2105-2116. doi:10.1021/om1009473.

[6] A.R. O'Connor, S.A. Urbin, R.A. Moorhouse, P.S. White, M. Brookhart, Organometallics 28 (2009) 2372-2384. doi:10.1021/om801103p.

[7] E.T. Singewald, X. Shi, C.A. Mirkin, S.J. Schofer, C.L. Stern, Organometallics 15 (1996) 3062-3069. doi:10.1021/om960114c.

[8] A.R. O’Connor, M. Brookhart, J. Polym. Sci. Part A: Polym. Chem. 48 (2010) 1901-1912. doi:10.1002/pola.23955.

[9] M.D. Walter, R.A. Moorhouse, P.S. White, M. Brookhart, J. Polym. Sci. Part A: Polym. Chem. 47 (2009) 2560-2573. doi:10.1002/pola.23340. 
[10] M.D. Walter, R.A. Moorhouse, S.A. Urbin, P.S. White, M. Brookhart, J. Am. Chem. Soc. 131 (2009) 9055-9069. doi:10.1021/ja9025598.

[11] A.R. O’Connor, W. Kaminsky, B.C. Chan, D.M. Heinekey, K.I. Goldberg, Organometallics 32 (2013) 4016-4019. doi:10.1021/om400266d.

[12] J.W. Faller, N. Sarantopoulos, Organometallics 23 (2004) 2008-2014. doi:10.1021/om030681h.

[13] D.S. Surry, S.L. Buchwald, Angew. Chem. Int. Ed. 47 (2008) 6338-6361. doi:10.1002/anie.200800497.

[14] A.J. DeAngelis, P.G. Gildner, R. Chow, T.J. Colacot, J. Org. Chem. 80 (2015) 67946813. doi:10.1021/acs.joc.5b01005.

[15] P.R. Melvin, A. Nova, D. Balcells, W. Dai, N. Hazari, D.P. Hruszkewycz, et al., ACS Catal. 5 (2015) 3680-3688. doi:10.1021/acscatal.5b00878.

[16] O. Diebolt, G.C. Fortman, H. Clavier, A.M.Z. Slawin, E.C. Escudero-Adán, J. BenetBuchholz, et al., Organometallics 30 (2011) 1668-1676. doi:10.1021/om101174x.

[17] R. Martin, S.L. Buchwald, Acc. Chem. Res. 41 (2008) 1461-1473. doi:10.1021/ar800036s.

[18] T.E. Barder, M.R. Biscoe, S.L. Organometallics 26 (2007) 2183-2192. doi:10.1021/om0701017.

[19] W.T. Dent, R. Long, A.J. Wilkinson, J. Chem. Soc. (1964) 1585-1588. doi:10.1039/JR9640001585.

[20] D. Alberti, R. Goddard, K.-R. Pörschke, Organometallics 24 (2005) 3907-3915. doi:10.1021/om050020f.

[21] E.S. Chernyshova, R. Goddard, K.-R. Pörschke, Organometallics 26 (2007) 3236-3251. doi:10.1021/om0702274.

[22] M. Yamashita, I. Takamiya, K. Jin, K. Nozaki, J. Organomet. Chem. 691 (2006) 31893195. doi:10.1016/j.jorganchem.2006.02.001.

[23] A.B. Pangborn, M.A. Giardello, R.H. Grubbs, R.K. Rosen, F.J. Timmers, Organometallics 15 (1996) 1518-1520. doi:10.1021/om9503712.

[24] N.A. Yakelis, R.G. Bergman, Organometallics 24 (2005) 3579-3581. doi:10.1021/om0501428.

[25] A. Aranyos, K.J. Szabó, A.M. Castaño, J.-E. Bäckvall, Organometallics 16 (1997) 10581064. doi:10.1021/om960950m.

[26] Bruker Instrument Service, Version 2010.1.0.0, Bruker AXS Inc., Madison, Wisconsin, USA, 2010.

[27] SAINT Plus, Data Reduction Software, Version 7.68A, Bruker AXS Inc., Madison, Wisconsin, USA, 2009.

[28] G.M. Sheldrick, A short history of it SHELX, Acta Crystallogr. A 64 (2008) 112-122. doi:10.1107/S0108767307043930.

[29] G.M. Sheldrick, Acta Crystallogr. C 71 (2015) 3-8. doi:10.1107/S2053273314026370.

[30] APEX2, Data Refinement Software, Version 2010.1-2, Bruker AXS Inc., Madison, Wisconsin, USA, 2010. 


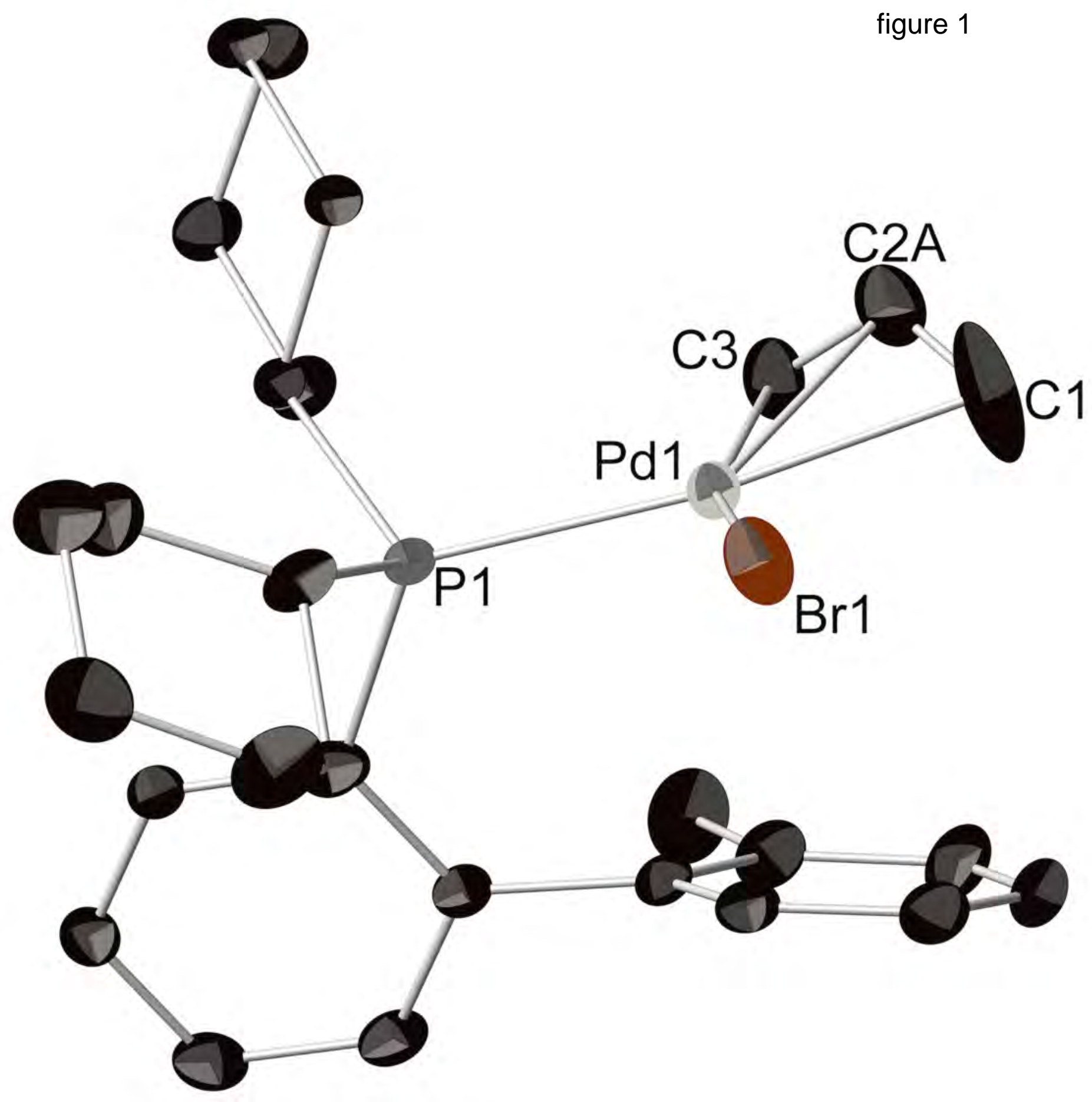




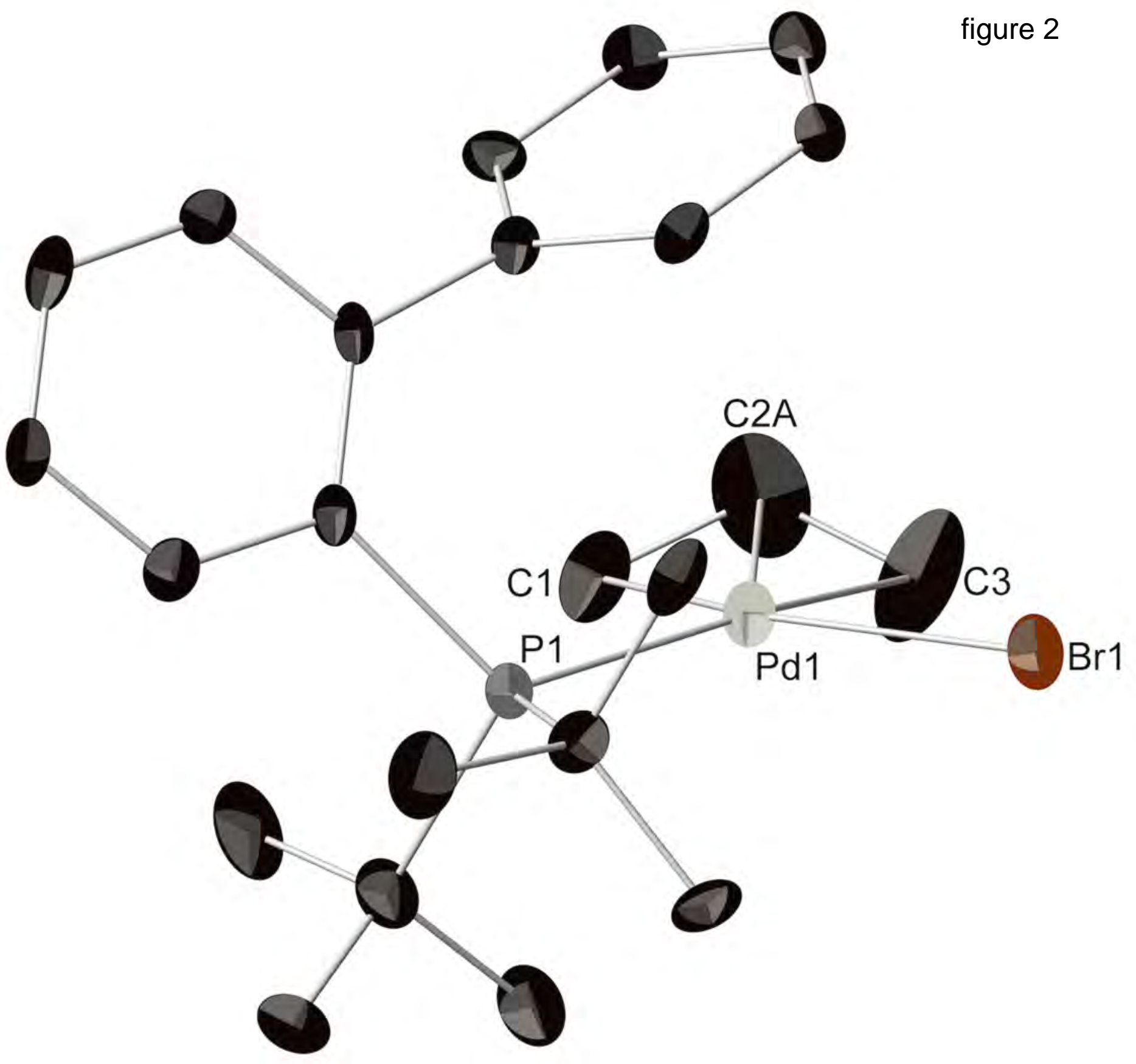


figure 3

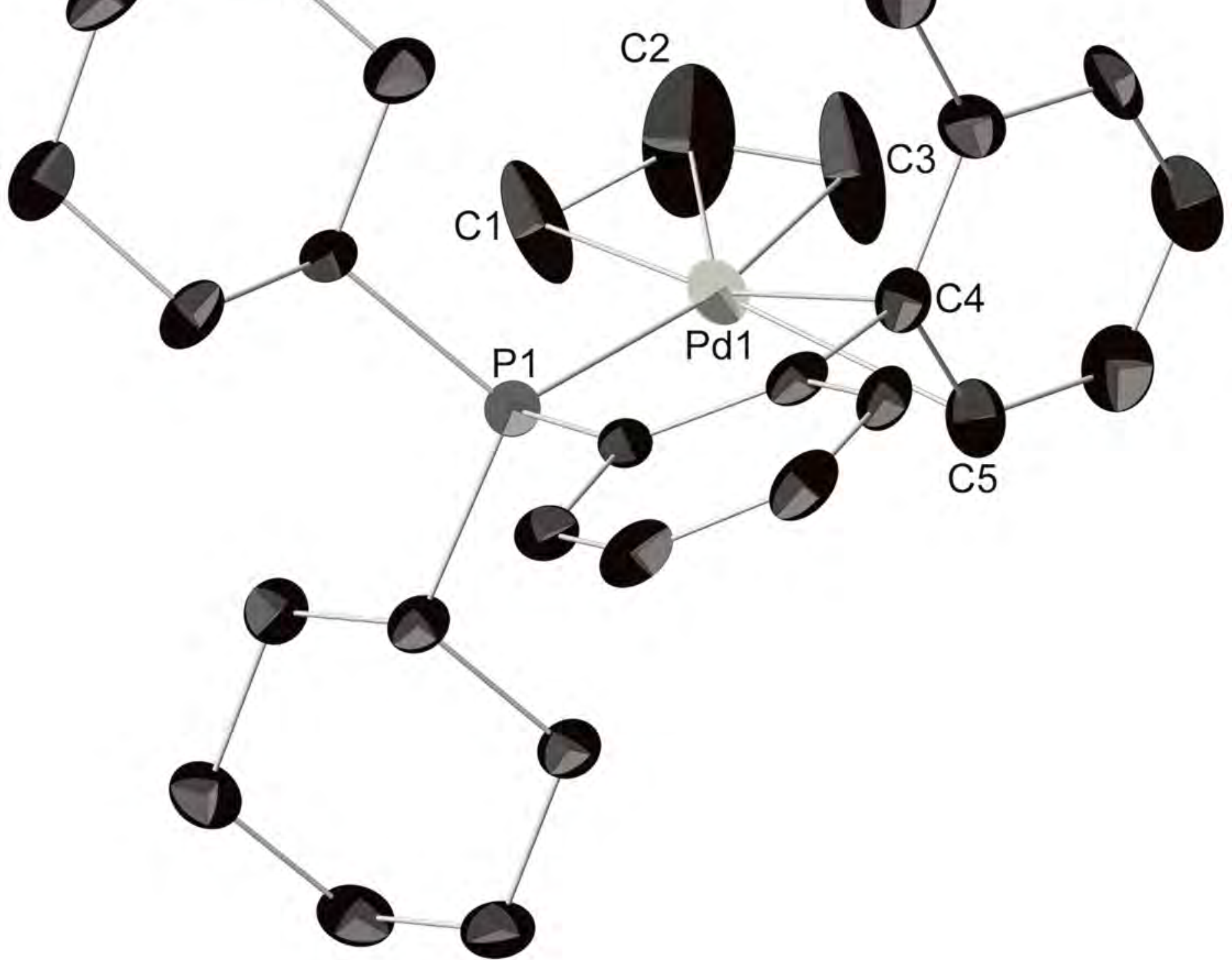




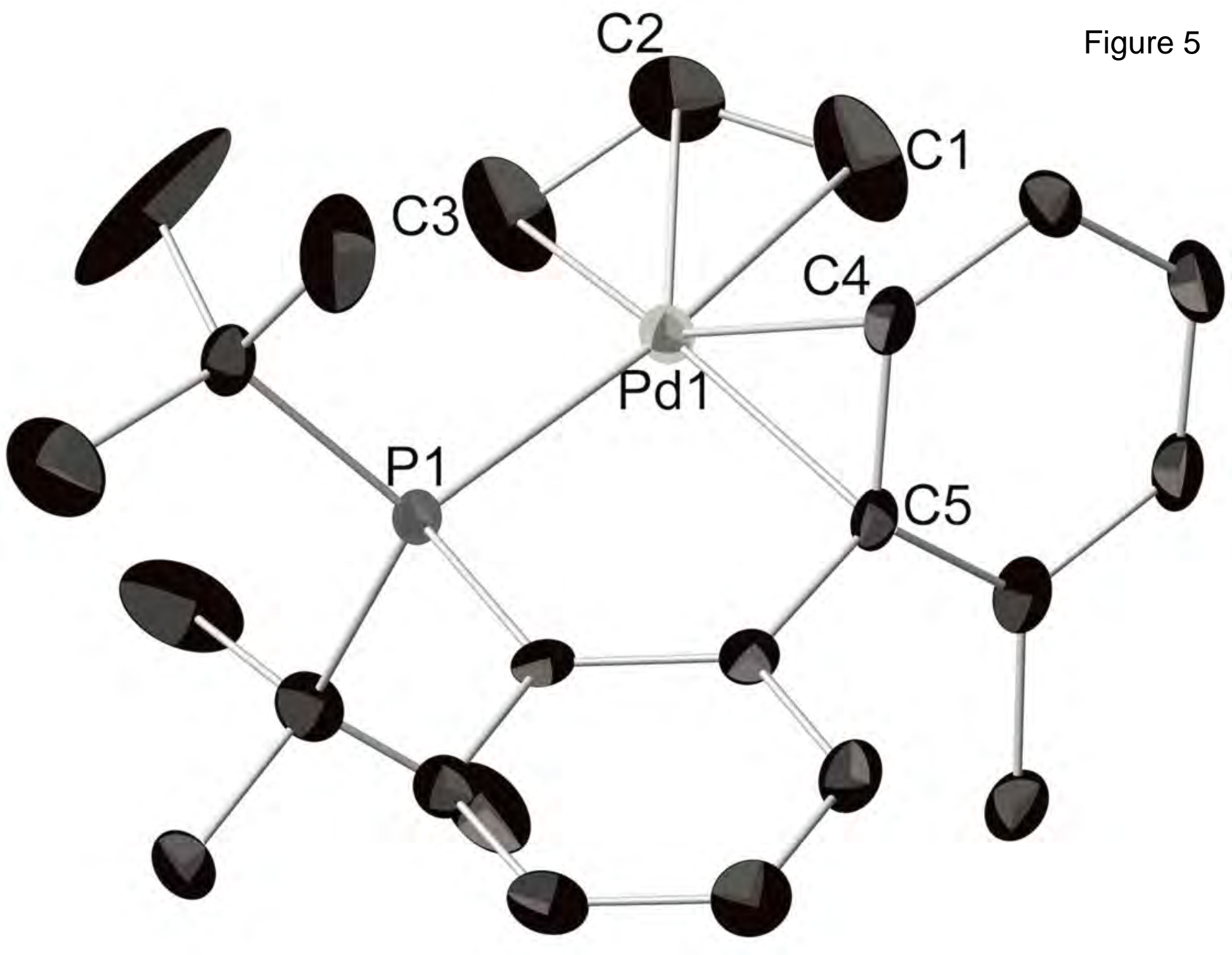


- Graphical abstract

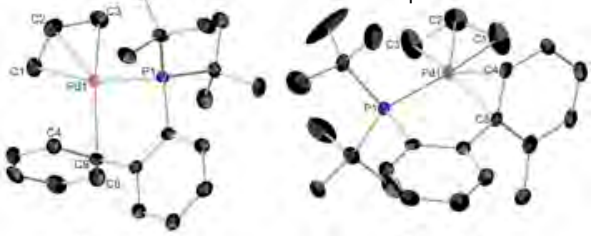

Complex 5

Complex 6 